\title{
Geochemistry and Geochronology of the Neoproterozoic Backarc Basin Khzama Ophiolite (Anti-Atlas Mountains, Morocco): Tectonomagmatic Implications
}

\author{
Latifa Chaib ${ }^{1}$, Abdelhak Ait Lahna ${ }^{1, *}$, Hassan Admou ${ }^{1}$, Nasrrddine Youbi ${ }^{1,2}{ }^{\mathbb{D}}$, Warda El Moume ${ }^{1}$, \\ Colombo Celso Gaeta Tassinari ${ }^{3}{ }^{(0}$, João Mata ${ }^{4}{ }^{\circ}$, Miguel Angelo Stipp Basei $\left.{ }^{5}{ }^{(}\right)$, Kei Sato ${ }^{3}$, Andrea Marzoli ${ }^{6}{ }^{(\mathbb{C}}$,

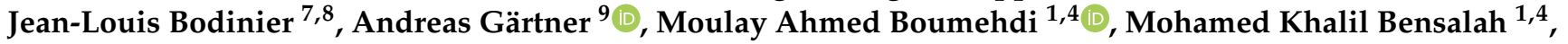 \\ Abderrahmane Soulaimani ${ }^{1}$, Kevin Hefferan ${ }^{10}$, Lhou Maacha ${ }^{11}$ and Amine Bajddi ${ }^{11}$
}

check for

updates

Citation: Chaib, L.; Ait Lahna, A.; Admou, H.; Youbi, N.; El Moume, W.; Tassinari, C.C.G.; Mata, J.; Basei, M.A.S.; Sato, K.; Marzoli, A.; et al. Geochemistry and Geochronology of the Neoproterozoic Backarc Basin Khzama Ophiolite (Anti-Atlas Mountains, Morocco): Tectonomagmatic Implications. Minerals 2021, 11, 56. https:// doi.org/10.3390/min11010056

Received: 12 November 2020

Accepted: 1 January 2021

Published: 9 January 2021

Publisher's Note: MDPI stays neutral with regard to jurisdictional clai$\mathrm{ms}$ in published maps and institutional affiliations.

Copyright: (C) 2021 by the authors. Licensee MDPI, Basel, Switzerland. This article is an open access article distributed under the terms and conditions of the Creative Commons Attribution (CC BY) license (https:// creativecommons.org/licenses/by/ $4.0 /)$
1 Department of Geology, Faculty of Sciences-Semlalia, Cadi Ayyad University, Prince Moulay Abdellah Boulevard, Marrakech 2390, Morocco; latifa_918@yahoo.fr (L.C.); admou@uca.ac.ma (H.A.); youbi@uca.ac.ma (N.Y.); warda.elmoume@gmail.com (W.E.M.); boumehdi@uca.ac.ma (M.A.B.); bensalah@uca.ac.ma (M.K.B.); soulaimani@gmail.com (A.S.)

2 Faculty of Geology and Geography, Tomsk State University, 36 Lenin Ave, 634050 Tomsk, Russia

3 Centro de Pesquisas Geocronológicas, Instituto de Geociências, Universidade de São Paulo, Caixa Postal 11348, Sao Paulo 05422-970, Brazil; ccgtassi@usp.br (C.C.G.T.); keisato@usp.br (K.S.)

4 Instituto Dom Luiz, Faculdade de Ciências, Universidade de Lisboa, 1749-016 Lisboa, Portugal; jmata@fc.ul.pt

5 Departamento de Mineralogia e Geotectônica, Instituto de Geociências, Universidade de São Paulo, Rua do Lago, 562 Cidade Universitária, Sao Paulo 05508-080, Brazil; baseimas@usp.br

6 Dipartimento Territorio e Sistemi Agro-Forestali, Università di Padova, 35020 Legnaro, Italy; andrea.marzoli@unipd.it

7 Geology and Sustainable Mining Department, Mohammed VI Polytechnic University, Hay Moulay Rachid, Ben Guerir 43150, Morocco; JeanLouis.Bodinier@um6p.ma

8 Géosciences Montpellier, Université de Montpellier 2, CNRS, Cc 60, Place Eugène Bataillon, CEDEX 05, 34095 Montpellier, France

9 Museum für Mineralogie und Geologie, Sektion Geochronologie, GeoPlasma Lab, Senckenberg Naturhistorische Sammlungen Dresden, Königsbrücker Landstraße 159, 01109 Dresden, Germany; Andreas.Gaertner@senckenberg.de

10 Massachusetts Maritime Academy, Department Marine Science, Safety, and Environmental Protection, 101 Academy Dr, Buzzards Bay, MA 02532, USA; khefferan@maritime.edu

11 Managem Group, Twin Center, Tour A, Angle Boulevards Zerktouni \& Al Massira Al Khadra, Casablanca 5199, Morocco; L.maacha@managemgroup.com (L.M.); a.bajddi@managemgroup.com (A.B.)

* Correspondence: aitlahna.abdelhak@gmail.com

\begin{abstract}
The Khzama ophiolite is a highly dismembered complex located in the Siroua inlier of the Moroccan Anti-Atlas Belt. It consists of ultramafic rocks, cumulate gabbros, sheeted dikes, pillow lavas, and an overlying volcano-sedimentary sequence. Three main tectonic slices of sheeted dike complexes are studied in detail along three rivers, exposing well preserved outcrops where individual dikes are clearly distinguishable from the intruded host rock (Assif n'Tinzla, Assif n'Tasriwine, and Assif n'Iriri). Sheeted dikes of the Khzama ophiolitic complex are basaltic to andesitic in composition, displaying a clear sub-alkaline nature. We identify two sets of dikes that originate from lower High-Ti series (HTS) lavas and overlying upper Low-Ti series (LTS) lava. The immobile trace-element signatures of these rocks point to a genesis on a backarc environment with magmas sourced in a supra-subduction zone (SSZ) at the spinel peridotite zone. The obtained SHRIMP U-Pb data of the gabbro represent the first radiometric age of zircon extracted from the mafic rocks that were intruded by the sheeted dike complex of the Khzama ophiolite. These grains yield a concordia age of $763 \pm 5 \mathrm{Ma}$, which is consistent with the $761.1+1.9 /-1.6$ and $762+1 /-2 \mathrm{Ma} \mathrm{U}-\mathrm{Pb}$ zircon ages of plagiogranites of Siroua. Based on their mineralogy, modal proportions, and major element chemistry, the felsic dikes are classified as high silica-low alumina trondhjemites or plagiogranites. These plagiogranites were likely formed by the partial melting of mafic rocks rather than by extreme fractional crystallization. A plagiogranite dated at $777 \pm 4.7 \mathrm{Ma}$ (U-Pb on zircon) is significantly older than the ca. 762 Ma plagiogranites previously recorded for the Khzama locality, suggesting a long-lived supra-subduction zone (SSZ) with conditions for the hydrous melting of mafic rocks.
\end{abstract}


Keywords: Anti-Atlas; Neoproterozoic Ophiolites; sheeted dikes; geochemistry; U-Pb geochronology

\section{Introduction}

Ophiolites are distinctive assemblages of ultramafic, mafic, and felsic igneous rocks, which are often associated with pelagic sediments and they have long been recognized as important components of Neoproterozoic and younger orogenic belts [1]. Ophiolites are fragments of oceanic lithosphere which have been tectonically emplaced into continents during convergent plate-tectonic processes. Both geochemistry and precise geochronology are required for their full characterization. Geochemical signatures of ophiolites provide key constraints on their geodynamic setting during formation, whereas their ages constrain when oceanic realms existed.

The tectonic origin of ophiolites can be broadly classified as either non-subduction or subduction-related [2,3]. Non-subduction-related ophiolites comprise continental margin, mid-ocean ridge (MORB), and plume types, whose magmatism was generated during the rifting and ocean floor spreading stages. Subduction-related or suprasubduction zone (SSZ) ophiolites comprise forearc, backarc, and island arc types, which formed within the intra-oceanic subduction system [2-8].

In the Neoproterozoic Anti-Atlas Belt of central Morocco (Figure 1A,B), the relics of oceanic crust (i.e., Bou-Azzer Group sensu [9]), are preserved in the Bou-Azzer (Aït Ahmane ophiolite) and Siroua (Khzama ophiolite) inliers as highly sheared allochthonous ophiolite complexes [10-12]. These ophiolitic assemblages are mainly made up of ultramafic rocks (serpentinites with chromite pods), but also include mafic meta-cumulates, meta-basaltic sheeted dikes, and, to a smaller extent, pillow lavas [13-15]. Their geochemical signature points to an emplacement in a supra-subduction zone setting [12,16-20]. The majority of published isotopic ages are within the range of circa 740 to $762 \mathrm{Ma}$ [12,20-22], but ages younger than $700 \mathrm{Ma}$ (down to $658 \pm 8 \mathrm{Ma}$ ) have also been reported [10,11], leaving open the discussion about the age of generation of magmatic rocks now preserved in the ophiolitic complexes.

This study examines structural, petrographical, chemical, and geochronological data of a sheeted dike complex in the Khzama ophiolite to constrain its tectonic setting and age. The geochemistry of gabbro, plagiogranites, and associated mafic sheeted dikes points to a supra-subduction zone (SSZ) tectonomagmatic setting and more precisely a backarc environment. We distinguish dikes that may be correlated with the basal High-Ti series (HTS) lavas from those of the overlying Low-Ti series (LTS) lavas. The first U-Pb dating of Khzama ophiolite on mafic rocks at $763 \pm 5 \mathrm{Ma}$ is consistent with the previous ca. $762 \mathrm{Ma}$ U-Pb zircon ages of plagiogranite obtained by [22], in the Khzama ophiolite. By contrast, a plagiogranite dated at $777 \pm 4.7 \mathrm{Ma}$ (U-Pb on zircon) is $15 \mathrm{Myr}$ older than the ca. 762 Ma plagiogranite of [22], suggesting a long-lived supra-subduction zone for the Neoproterozoic Khzama ophiolite. 

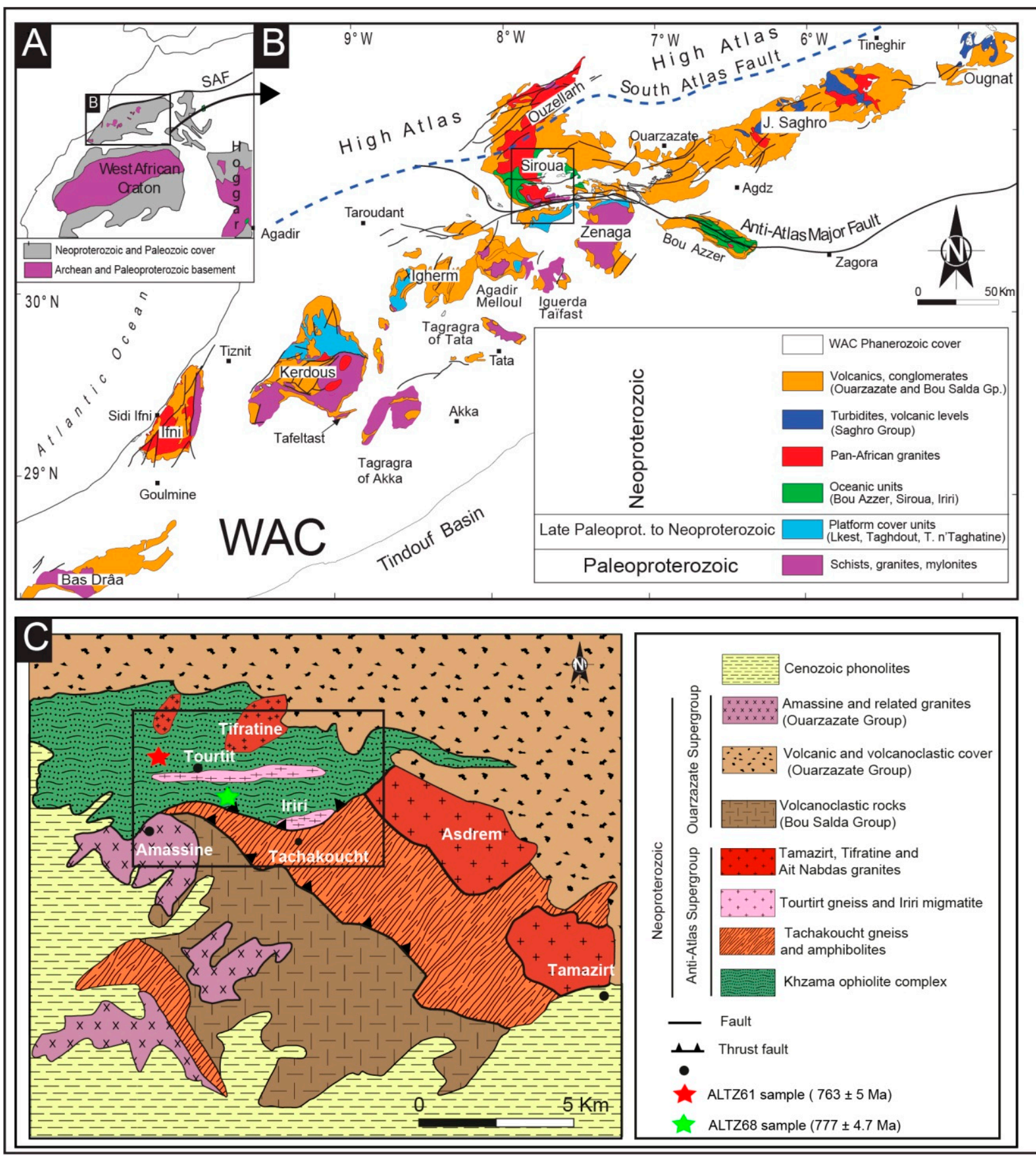

Figure 1. (A) Location of the Anti-Atlas Belt in Northwestern Africa; (B) Geological map of the Anti-Atlas Belt in southern Morocco showing the studied area in the Siroua inlier [23], modified by [24]. (C) Simplified geological map of the central part of Khzama inlier showing the main lithotectonic units (modified after [25]). The localities (Tourtit, Amassine, and Tachakoucht) mentioned in the text are indicated, as well as the location of Figure 2 and the samples used for U-Pb geochronology. Abbreviations; WAC = West African craton. Gp. = Group; T. = Tizi. Note that the northern boundary of the WAC is the Anti-Atlas Major Faults or the South Atlas Fault [26]. 


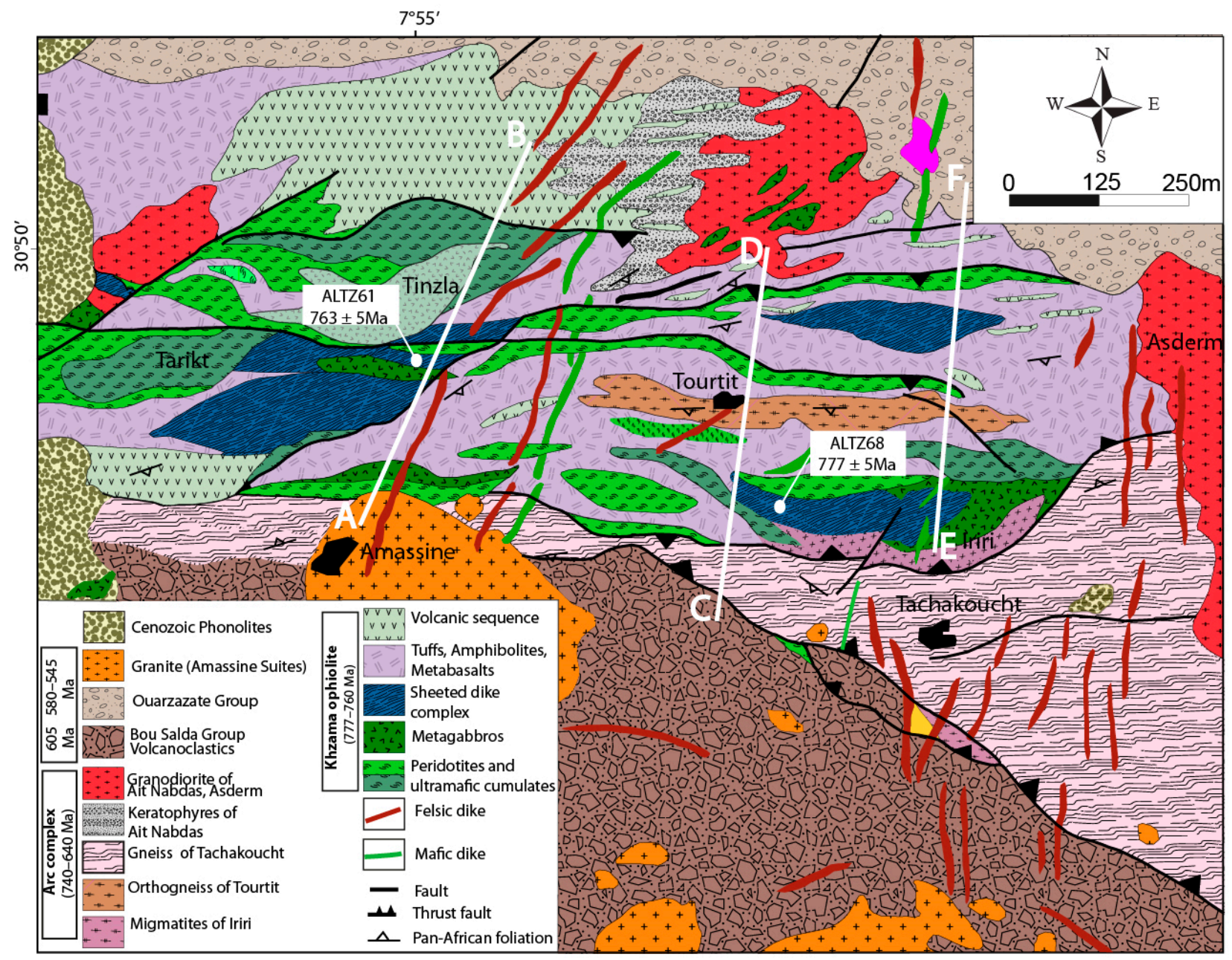

Figure 2. Geological map of central part of Khzama Inlier (adopted from [25]). The locations of the studied three cross sections along the Khzama inlier are indicated.

\section{Geological Background}

The erosional inlier of Siroua (Anti-Atlas) exposes distinct Late-Precambrian lithotectonic units in the region of Khzama (Figure 1C; see [25]). The Tachakoucht Formation, containing undated mica schists and gneisses, is overthrusted, with a southward vergence, by the Iriri migmatites, both forming the metamorphic complex known as "TachakouchtIriri-Tourtit" [27]. The Tachakoucht-Iriri-Tourtit and arc-related units, including the studied Khzama ophiolite, contain four different sub-units. From south to north, these include: (1) the Tachakoucht gneisses (740-720 Ma) intruded in northern outcrop exposures by (2) Iriri intrusions (660-640 Ma). Also along the northern exposures, the Tachakoucht-Iriri massif is overthrusted by (3) the south-verging 760 Ma Khzama ophiolitic sequence and intruded by (4) the Tourtit meta-granitic complex (640 Ma).

The geological history is summarized as follows. The Tachakoucht gneiss represents former andesitic to dacitic porphyritic rocks that crystallized around 740-720 Ma in an intra-oceanic arc setting. Subsequently, these rocks were buried and metamorphosed due to an early accretion of the arc onto the West African Craton (WAC). This tectonometamorphic event also led resulted in the dismembering and stacking of a backarc basin ophiolite onto the arc complex. Subsequently, the Iriri intrusions intruded the Tachakoucht gneiss. The Iriri intrusions are a suite of hydrous mafic dykes (hornblende gabbro and finegrained basalt) and ultramafic (hornblendite) plutons showing subduction zone affinities. The entire complex was overprinted by a second deformation event under greenschist to amphibolite facies conditions which was marked by transposition of primary structures and a development of mylonitic shear zones $[21,25,27,28]$. 
The age at $743 \pm 14 \mathrm{Ma}$ resulting from $\mathrm{U}-\mathrm{Pb}$ Sensitive High Resolution Ion Microprobe (SHRIMP) analysis of zircon from tonalitic gneiss [21] is thought to represent the protolith age of the Iriri migmatite. This complex was interpreted as having formed during the Pan-African collision, being a root of accreted oceanic arc affected by high temperature and medium pressure metamorphism [21,27]). Further to the north, a dismembered ophiolite was identified $[9,11-13,15,21,25,29-34]$. The boundary between this ophiolitic complex and the underlying deformed Iriri-Tachakoucht complex is marked by a 'serpentinite brecciated mélange' composed by tectonically rounded blocks of serpentinites within a fine-grained matrix of crushed serpentinite and talc-schist [27]. This ophiolite, termed the Tasriwine ophiolite by [21] and referred to as Khzama ophiolite in this work, consists of slices of ultramafic rocks (and their serpentinized equivalents), gabbroic rocks, and a sheeted dike complex [25] (Figures 2 and 3). The Khzama ophiolite is strongly tectonized/mylonitized and amphibolitized. The extensive deformation and metamorphism of the Khzama ophiolite, including the mylonitized and amphibolitized sheeted dikes and flaser gabbros and their contact relationships, are typical of transform fault environments [30,35-37]. Three cross sections were established in the Khzama region (Figures 2 and 3). Three Khzama complex cross sections (Figures 2 and 3) illustrate fault bounded ophiolite units underlain by Pan African shear zone mylonites. Brittle faults and ductile shear zones indicate predominant sinistral oblique thrusting to the south, although some antithetic structures record displacement to the north $[25,38]$. The synthetic stratigraphic column of the Khzama ophiolite complex contains, from bottom to top, a succession of (Figure 4):

(i) A 200-250 m thick unit of mantle tectonites which consists of folded ultramafic mantle and cumulate rocks exposed along shear zones. These ultramafic rocks, comprising pyroxenites, wehrlites, dunites, and serpentinized harzburgites, are residual facies characterized by plastic deformation and a mylonitic texture. They occur both as isolated tectonic slices, and in stratigraphic continuity with ultrabasic cumulate rocks. Locally, they display primary bedding marked by discontinuous grains of chromite and magnetite. The primary phenocrysts of olivine and pyroxene have been strongly metamorphosed to metabasites and serpentines. Serpentinites are particularly common in ductile shear zones.

(ii) A 150-200 m thick sequence of gabbros (pyroxene-rich at the base), with minor hornblendite pegmatite, pyroxenite, diabase, and anorthosite [25]. This sequence also contains alternating layers of pyroxenite, dunite, harzburgite, wehrlite + / - gabbros. Magmatic bedding is on centimeter to meter scale distinguished on the basis of mineral phases or granular texture. In the southwest part of the study area, Tarikt syncline displays repetitive bedding sequences over $150 \mathrm{~m}$ thick. The dated leucogabbro (sample ALTZ61) belongs to this unit.

(iii) A very well-developed sheeted dike complex (up to $800 \mathrm{~m}$ thick) intrudes the previously described gabbroic unit. This unit consists of sub-vertical diabase and gabbroic dikes. Several sheeted dike complexes are recognized in the Khzama inlier (Figure 2). This complex also contains an isolated dike system of plagiogranites.

(iv) A 700-800 m thick volcanic unit containing basaltic flows and tuffs unconformably overlain by keratophyres and felsic tuffs. This sequence is intruded by a wehrlitic and gabbro-diorite intrusion approximately $40 \mathrm{~m}$ in diameter.

The Khzama ophiolitic complex units were intruded by calc-alkaline magma bodies. The calc alkaline bodies have been deformed and metamorphosed to gneissic complexes related to arc systems formed during the convergence phase (Tachakoucht, Iriri, Tourtit). During this convergence, these units underwent strong foliation and mylonitization. 


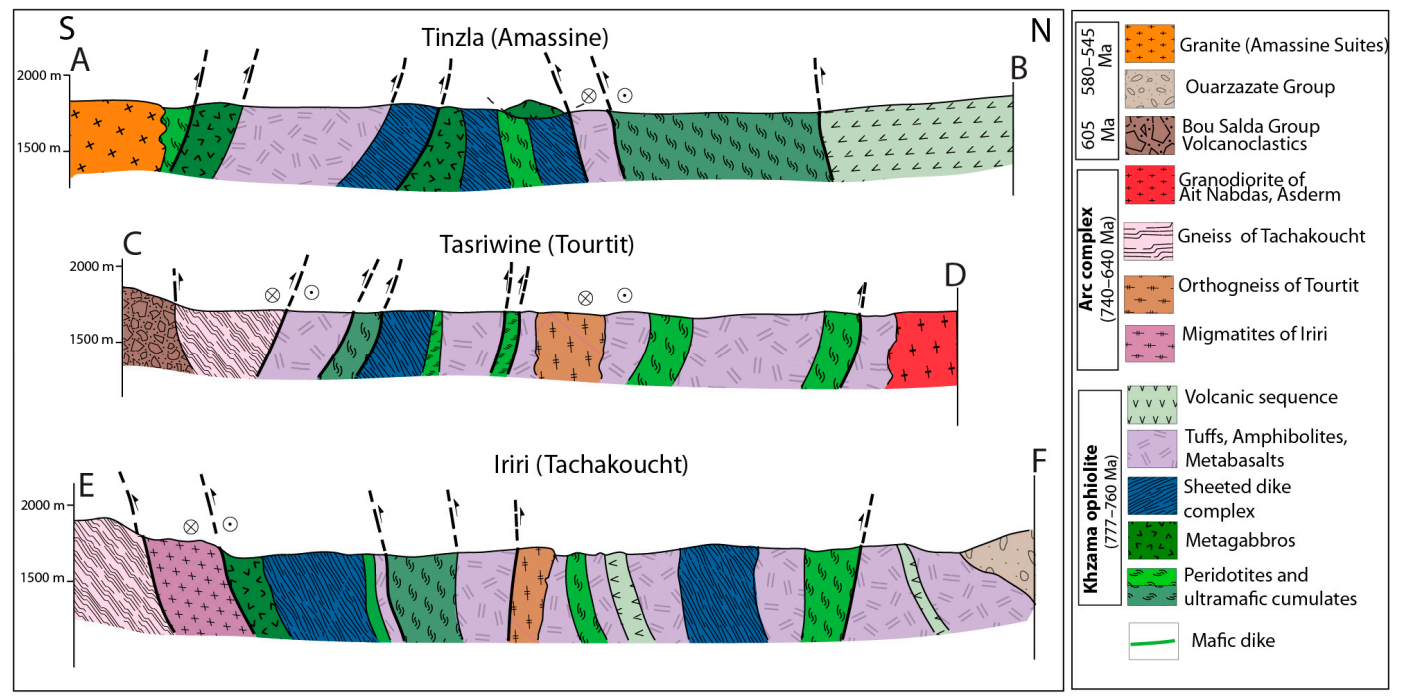

Figure 3. Cross sections along the three studied localities in the Khzama inlier.

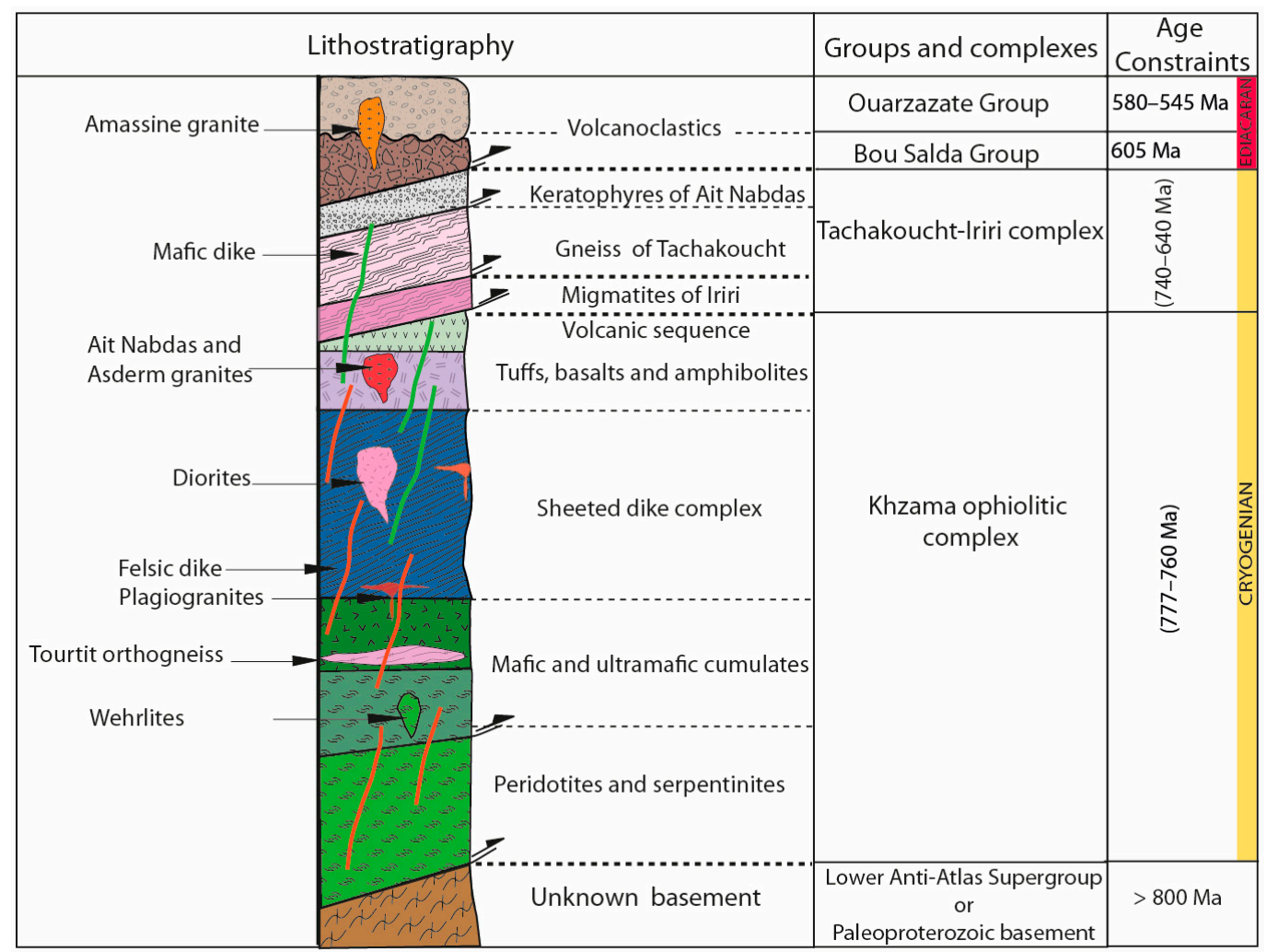

Figure 4. Synthetic stratigraphic column of Khzama ophiolite (adopted from [25,29]).

\section{Sampling and Analytical Procedures \\ 3.1. Sampling}

To determine tectonic origin and age of the Khzama ophiolite sheeted dike complex, we collected samples from 12 mafic and 8 felsic dikes for major and trace element analyses (Table 1). Two samples were dated using SHRIMP U-Pb zircon geochronology; the first sample was taken from a felsic dike (plagiogranite) cropping out at the Assif $\mathrm{n}^{\prime}$ 'Tasriwine $\left(\mathrm{N} 30^{\circ} 48^{\prime} 45.7^{\prime \prime}, \mathrm{W} 7^{\circ} 32^{\prime} 29.1^{\prime \prime}\right)$ and the second one was collected from the leucogabbros of plutonic sequence of the Khzama ophiolitic complex (Assif n'Tinzla; N30 $49^{\prime} 47.2^{\prime \prime}$, W7 $34^{\prime} 48.3^{\prime \prime}$ ) (Figure 2). 
Table 1. Whole-rock major and trace element geochemical data for dikes and felsic rocks from the Siroua inlier including the dated samples ALTZ61 and ALTZ68.

\begin{tabular}{|c|c|c|c|c|c|c|c|c|c|c|c|}
\hline \multicolumn{12}{|c|}{ (a) } \\
\hline \multirow{2}{*}{ Samples } & \multicolumn{11}{|c|}{ Mafic Dikes } \\
\hline & AHCF1 & AHCF2 & AHCF3 & AHCF5 & AHCF8 & АHCF397 & AHCF445 & AHCF453 & AHCF396 & AHCF439D & AHCF440D \\
\hline Longitude W & $7^{\circ} 34^{\prime} 57^{\prime \prime}$ & $7^{\circ} 34^{\prime} 57^{\prime \prime}$ & $7^{\circ} 35^{\prime} 2^{\prime \prime}$ & $7^{\circ} 34^{\prime} 12.4^{\prime \prime}$ & $7^{\circ} 34^{\prime} 57.4^{\prime \prime}$ & $7^{\circ} 35^{\prime} 11.3^{\prime \prime}$ & $7^{\circ} 35^{\prime} 10.3^{\prime \prime}$ & $7^{\circ} 35^{\prime} 13^{\prime \prime}$ & $7^{\circ} 34^{\prime} 57.3^{\prime \prime}$ & $7^{\circ} 34^{\prime} 57.2^{\prime \prime}$ & $7^{\circ} 35^{\prime} 0.2^{\prime \prime}$ \\
\hline Latitude N & $30^{\circ} 49^{\prime} 2^{\prime \prime}$ & $30^{\circ} 49^{\prime} 5^{\prime \prime}$ & $30^{\circ} 49^{\prime} 3^{\prime \prime}$ & $30^{\circ} 49^{\prime} 2^{\prime \prime}$ & $30^{\circ} 49^{\prime} 12.3^{\prime \prime}$ & $30^{\circ} 49^{\prime} 4.8^{\prime \prime}$ & $30^{\circ} 49^{\prime} 2.6^{\prime \prime}$ & $30^{\circ} 49^{\prime} 0^{\prime \prime}$ & $30^{\circ} 49^{\prime} 0.8^{\prime \prime}$ & $30^{\circ} 49^{\prime} 3.51^{\prime \prime}$ & $30^{\circ} 49^{\prime} 0.23^{\prime \prime}$ \\
\hline \multicolumn{12}{|l|}{$w t \%$} \\
\hline $\mathrm{SiO}_{2}$ & 55.90 & 50.00 & 58.00 & 58.00 & 49.60 & 49.70 & 44.40 & 45.10 & 57.10 & 51.10 & 49.10 \\
\hline $\mathrm{Al}_{2} \mathrm{O}_{3}$ & 16.30 & 15.20 & 15.30 & 14.40 & 14.10 & 16.90 & 19.80 & 19.70 & 15.80 & 13.65 & 15.35 \\
\hline $\mathrm{FeO}$ & 7.02 & 8.69 & 8.51 & 8.69 & 12.33 & 11.39 & 10.58 & 10.49 & 8.24 & 12.47 & 11.66 \\
\hline $\mathrm{MnO}$ & 0.12 & 0.18 & 0.15 & 0.15 & 0.24 & 0.20 & 0.23 & 0.19 & 0.15 & 0.45 & 0.24 \\
\hline $\mathrm{MgO}$ & 6.07 & 7.95 & 3.87 & 4.55 & 5.05 & 5.42 & 5.50 & 5.58 & 4.55 & 4.72 & 5.50 \\
\hline $\mathrm{CaO}$ & 6.60 & 11.50 & 7.75 & 9.50 & 8.65 & 8.65 & 7.95 & 10.00 & 8.60 & 8.30 & 7.21 \\
\hline $\mathrm{Na}_{2} \mathrm{O}$ & 5.36 & 2.42 & 2.60 & 0.87 & 3.58 & 1.64 & 2.51 & 3.09 & 1.30 & 3.14 & 4.22 \\
\hline $\mathrm{K}_{2} \mathrm{O}$ & 0.40 & 0.13 & 0.24 & 0.07 & 0.20 & 0.11 & 2.37 & 1.14 & 0.05 & 0.23 & 0.50 \\
\hline $\mathrm{TiO}_{2}$ & 0.25 & 0.58 & 0.31 & 0.13 & 2.34 & 0.70 & 1.15 & 0.93 & 0.37 & 2.41 & 2.18 \\
\hline $\mathrm{P}_{2} \mathrm{O}_{5}$ & 0.06 & 0.07 & 0.08 & 0.05 & 0.34 & 0.09 & 0.25 & 0.28 & 0.07 & 0.46 & 0.37 \\
\hline LOI & 1.37 & 2.21 & 1.85 & 2.64 & 1.67 & 3.49 & 3.68 & 1.65 & 2.87 & 1.27 & 2.42 \\
\hline Total & 100.2 & 99.89 & 99.60 & 100.01 & 99.47 & 99.55 & 99.59 & 99.31 & 100.02 & 99.58 & 100.04 \\
\hline Mg\# & 0.63 & 0.64 & 0.47 & 0.51 & 0.45 & 0.49 & 0.51 & 0.51 & 0.52 & 0.43 & 0.48 \\
\hline \multicolumn{12}{|l|}{$\mathrm{ppm}$} \\
\hline $\mathrm{Sc}$ & 30.00 & 41.00 & 32.50 & 46.00 & 41.00 & 42.00 & 27.00 & 24.00 & 32.50 & 39.00 & 40.00 \\
\hline Co & 30 & 48 & 28 & 29 & 47 & 37 & 32 & 37 & 24 & 39 & 37 \\
\hline $\mathrm{Ni}$ & 78 & 81 & 27 & 49 & 26 & 25 & 18 & 17 & 36 & 16 & 32 \\
\hline $\mathrm{Rb}$ & 9 & 3 & 5 & 1 & 2 & 5 & 100 & 25 & 1 & 2 & 8 \\
\hline $\mathrm{Sr}$ & 432 & 130 & 152 & 97 & 163 & 150 & 580 & 550 & 136 & 347 & 277 \\
\hline $\mathrm{Cu}$ & - & - & - & - & - & - & - & - & - & - & - \\
\hline $\mathrm{Zn}$ & - & - & - & - & - & - & - & - & - & - & - \\
\hline $\mathrm{Ga}$ & - & - & - & - & - & - & - & - & - & - & - \\
\hline Y & 6 & 15 & 8 & 4 & 44 & 17 & 24 & 26 & 11 & 40 & 37 \\
\hline $\mathrm{Zr}$ & 6 & 15 & 22 & 20 & 100 & 18 & 12 & 19 & 17 & 51 & 51 \\
\hline $\mathrm{Nb}$ & 0 & 1 & 1 & 1 & 5 & 1 & 3 & 3 & 2 & 8 & 6 \\
\hline Cs & - & - & - & - & - & - & - & - & - & - & - \\
\hline $\mathrm{Ba}$ & 88 & 44 & 75 & 21 & 75 & 25 & 795 & 175 & 26 & 82 & 97 \\
\hline $\mathrm{La}$ & 1.05 & 1.05 & 1.50 & 0.50 & 9.20 & 1.80 & 3.00 & 6.50 & 2.30 & 14.50 & 15.50 \\
\hline $\mathrm{Ce}$ & 3.50 & 3.50 & 4.40 & 2.50 & 25.50 & 4.50 & 9.00 & 20.00 & 4.00 & 34.00 & 37.00 \\
\hline $\mathrm{Pr}$ & - & - & - & - & - & - & - & - & - & - & - \\
\hline $\mathrm{Nd}$ & 1.70 & 2.50 & 1.90 & 1.00 & 21.00 & 3.60 & 8.60 & 17.50 & 3.00 & 23.50 & 25.00 \\
\hline $\mathrm{Sm}$ & - & - & - & - & - & 1.35 & 3.00 & 5.00 & 0.90 & 6.10 & 6.55 \\
\hline $\mathrm{Eu}$ & 0.40 & 0.55 & 0.35 & 0.20 & 2.02 & 0.53 & 1.10 & 1.50 & 0.30 & 2.10 & 2.10 \\
\hline
\end{tabular}


Table 1. Cont.

\begin{tabular}{|c|c|c|c|c|c|c|c|c|c|c|c|}
\hline \multirow{3}{*}{ Samples } & \multicolumn{11}{|c|}{ (a) } \\
\hline & \multicolumn{11}{|c|}{ Mafic Dikes } \\
\hline & AHCF1 & AHCF2 & AHCF3 & AHCF5 & AHCF8 & AHCF397 & AHCF445 & AHCF453 & AHCF396 & AHCF439D & AHCF440D \\
\hline Longitude W & $7^{\circ} 34^{\prime} 57^{\prime \prime}$ & $7^{\circ} 34^{\prime} 57^{\prime \prime}$ & $7^{\circ} 35^{\prime} 2^{\prime \prime}$ & $7^{\circ} 34^{\prime} 12.4^{\prime \prime}$ & $7^{\circ} 34^{\prime} 57.4^{\prime \prime}$ & $7^{\circ} 35^{\prime} 11.3^{\prime \prime}$ & $7^{\circ} 35^{\prime} 10.3^{\prime \prime}$ & $7^{\circ} 35^{\prime} 13^{\prime \prime}$ & $7^{\circ} 34^{\prime} 57.3^{\prime \prime}$ & $7^{\circ} 34^{\prime} 57.2^{\prime \prime}$ & $7^{\circ} 35^{\prime} 0.2^{\prime \prime}$ \\
\hline Latitude N & $30^{\circ} 49^{\prime} 2^{\prime \prime}$ & $30^{\circ} 49^{\prime} 5^{\prime \prime}$ & $30^{\circ} 49^{\prime} 3^{\prime \prime}$ & $30^{\circ} 49^{\prime} 2^{\prime \prime}$ & $30^{\circ} 49^{\prime} 12.3^{\prime \prime}$ & $30^{\circ} 49^{\prime} 4.8^{\prime \prime}$ & $30^{\circ} 49^{\prime} 2.6^{\prime \prime}$ & $30^{\circ} 49^{\prime} 0^{\prime \prime}$ & $30^{\circ} 49^{\prime} 0.8^{\prime \prime}$ & $30^{\circ} 49^{\prime} 3.51^{\prime \prime}$ & $30^{\circ} 49^{\prime} 0.23^{\prime \prime}$ \\
\hline $\mathrm{Gd}$ & - & - & - & - & - & 1.95 & 3.80 & 4.80 & 1.40 & 6.80 & 6.85 \\
\hline $\mathrm{Tb}$ & - & - & - & - & - & - & - & - & - & - & - \\
\hline Dy & 1.10 & 2.30 & 1.20 & 0.60 & 7.50 & 2.50 & 4.15 & 4.60 & 1.50 & 7.00 & 6.60 \\
\hline Ho & - & - & - & - & - & - & - & - & - & - & - \\
\hline $\mathrm{Er}$ & 0.70 & 1.50 & 0.90 & 0.40 & 4.40 & 1.60 & 2.30 & 2.60 & 1.30 & 3.60 & 3.50 \\
\hline $\mathrm{Yb}$ & 0.65 & 1.55 & 0.96 & 0.64 & 4.00 & 1.90 & 2.25 & 2.60 & 1.34 & 3.45 & 3.20 \\
\hline $\mathrm{Lu}$ & - & - & - & - & - & - & - & - & - & - & - \\
\hline $\mathrm{Hf}$ & - & - & - & - & - & - & - & - & - & - & - \\
\hline $\mathrm{Ta}$ & - & - & - & - & - & - & - & - & - & - & - \\
\hline Th & - & - & - & - & - & 0.20 & 0.00 & 0.40 & 0.40 & 1.20 & 1.30 \\
\hline $\mathrm{Pb}$ & - & - & - & - & - & - & - & - & - & - & - \\
\hline $\mathrm{U}$ & - & - & - & - & - & - & - & - & - & - & - \\
\hline As & - & - & - & - & - & - & - & - & - & - & - \\
\hline $\mathrm{Be}$ & - & - & - & - & - & - & - & - & - & - & - \\
\hline $\mathrm{Bi}$ & - & - & - & - & - & - & - & - & - & - & - \\
\hline In & - & - & - & - & - & - & - & - & - & - & - \\
\hline Mo & - & - & - & - & - & - & - & - & - & - & - \\
\hline $\mathrm{Sb}$ & - & - & - & - & - & - & - & - & - & - & - \\
\hline Sn & - & - & - & - & - & - & - & - & - & - & - \\
\hline W & - & - & - & - & - & - & - & - & - & - & - \\
\hline $\mathrm{La}_{n}$ & 4.43 & 4.43 & 6.33 & 2.11 & 38.82 & 7.59 & 12.66 & 27.43 & 9.70 & 61.18 & 65.40 \\
\hline$(\mathrm{La} / \mathrm{Yb})_{\mathrm{n}}$ & 1.16 & 0.49 & 1.12 & 0.56 & 1.65 & 0.68 & 0.96 & 1.79 & 1.23 & 3.01 & 3.47 \\
\hline$(\mathrm{La} / \mathrm{Sm})_{\mathrm{n}}$ & - & - & - & - & - & 0.86 & 0.65 & 0.84 & 1.65 & 1.53 & 1.53 \\
\hline$(\mathrm{Gd} / \mathrm{Lu})_{\mathrm{n}}$ & - & - & - & - & - & - & - & - & - & - & - \\
\hline ACNK & 0.96 & 0.79 & 1.06 & 1.02 & 0.83 & 1.19 & 1.10 & 1.00 & 1.17 & 0.85 & 0.93 \\
\hline $\mathrm{Nb} / \mathrm{Yb}$ & 0.62 & 0.90 & 1.04 & 0.78 & 1.28 & 0.68 & 1.24 & 1.15 & 1.19 & 2.23 & 1.94 \\
\hline $\mathrm{Th} / \mathrm{Yb}$ & - & - & - & - & - & 0.11 & 0.00 & 0.15 & 0.30 & 0.35 & 0.41 \\
\hline $\mathrm{Ti} / \mathrm{V}$ & 6.24 & 13.80 & 6.19 & 2.78 & 35.52 & 11.37 & 27.04 & 24.89 & 8.47 & 35.24 & 37.66 \\
\hline $\mathrm{Ba} / \mathrm{Zr}$ & 14.67 & 2.93 & 3.41 & 1.05 & 0.75 & 1.39 & 66.25 & 9.21 & 1.53 & 1.61 & 1.90 \\
\hline $\mathrm{Nb} / \mathrm{Zr}$ & 0.07 & 0.09 & 0.05 & 0.03 & 0.05 & 0.07 & 0.23 & 0.16 & 0.09 & 0.15 & 0.12 \\
\hline $\mathrm{Ce} / \mathrm{Yb}$ & 5.38 & 2.26 & 4.58 & 3.91 & 6.38 & 2.37 & 4.00 & 7.69 & 2.99 & 9.86 & 11.56 \\
\hline
\end{tabular}


Table 1. Cont.

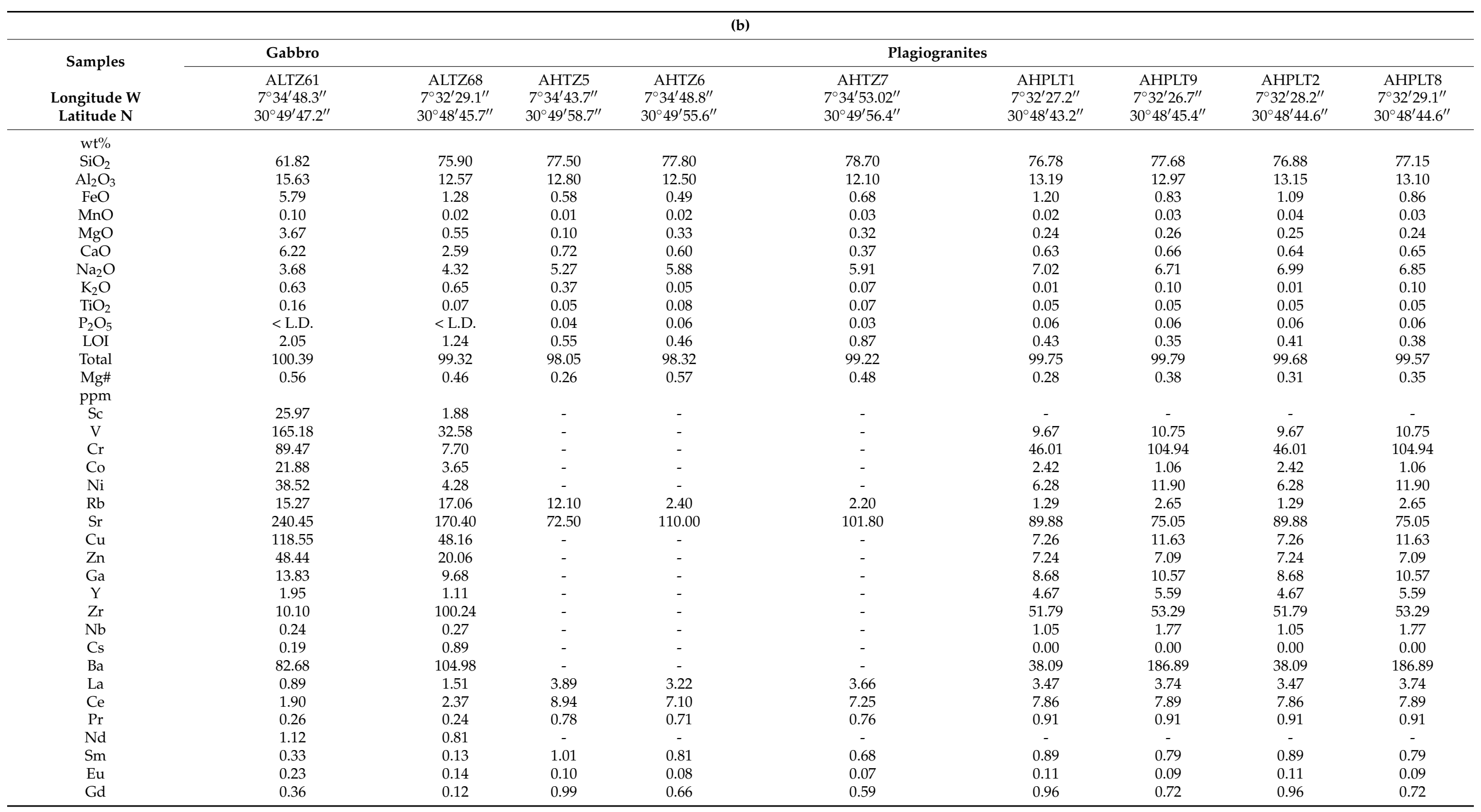


Table 1. Cont.

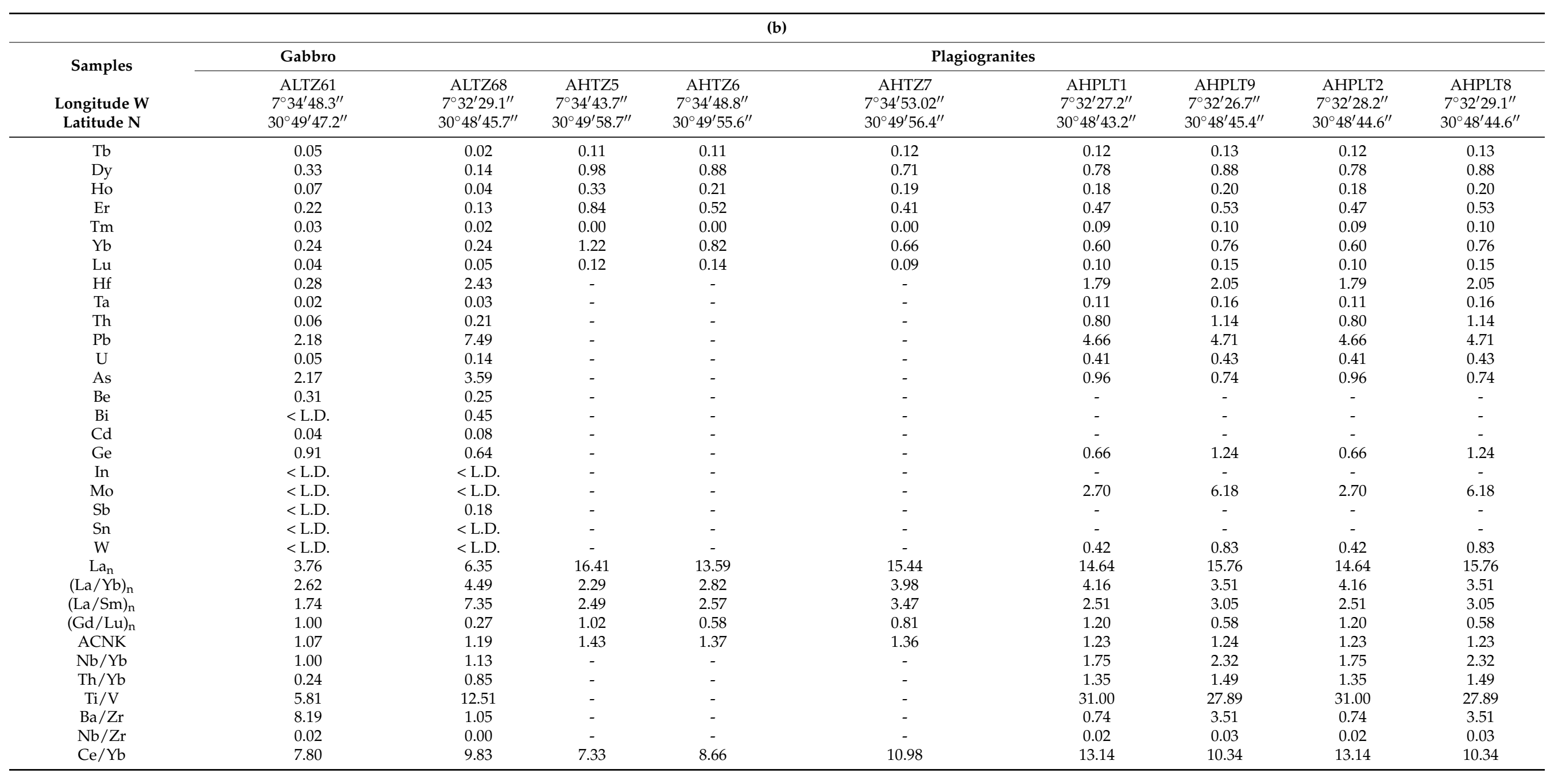




\subsection{Whole Rock Geochemistry}

Elemental whole-rocks analyses of the studied rocks are listed in Table 1. The samples for analyses were selected based on their representativeness and freshness. They were powdered in an agate swing mill after crushing to centimeter sized chips, which were after selected based on the absence of signs of alteration and lack of secondary minerals.

Samples labeled as AHCF were analyzed at the "Département des Sciences de la Terre de l'Université de Bretagne Occidentale", Brest (France), using the methodology described in detail by [39]. For all the elements but $\mathrm{Rb}$, inductively coupled plasmaatomic emission spectrometry (ICP-AES) was used with an ISA Jobin-Yvon JY 70 Plus apparatus spectrometer. $\mathrm{Rb}$ was analyzed by flame atomic emission using a PerkinElmer 5000 spectrometer. The quality of analyses was assessed using international standards (ACE, BEN, JB-2, PMS, and WS-E). Relative standard deviations are $\pm 1 \%$ for $\mathrm{SiO}_{2}$ and $\pm 2 \%$ for other major elements except $\mathrm{P}_{2} \mathrm{O}_{5}$ and $\mathrm{MnO}( \pm 0.01 \%)$, and ca. $5 \%$ for trace elements.

Analyses for samples labelled ALTZ, AHTZ, and AHPLT were performed at "Service d'Analyse des Roches et des Minéraux" at the Geochemical and Petrographical Research Center in Nancy (SARM laboratory-CRPG-CNRS, Nancy, France) using inductively coupled plasma atomic emission spectroscopy (ICP-AES) for major elements and inductively coupled mass spectrometry (ICP-MS) for trace elements. International standards (Basalt BEN, Basalt BR, Dolerite WS-E, and Microgabbro PM-S) were used for calibration. More details on the analytical procedures can be found at http://helium.crpg.cnrs-nancy.fr/SARM/.

\subsection{U-Pb Geochronology}

Zircon grains were extracted from crushed (3-5 kg) rocks using conventional techniques using magnetic (Frantz isodynamic magnetic separator) and density (Wilfley table, bromoform, and methylene iodide). For each sample, about 20 zircon grains were mounted in epoxy resin, polished and coated with Au. Images of the zircon grains internal textures were obtained using a Quanta 250 FEG scanning electron microscope equipped with Mono CL3+ cathodoluminescence spectroscope (Centaurus) at the Centro de Pesquisas Geocronológicas of the University of São Paulo (CPGeo-USP), Brazil. $60 \mu \mathrm{A}$ emission current, $15.0 \mathrm{kV}$ accelerating voltage, $7 \mu \mathrm{m}$ beam diameter, $200 \mu$ s acquisition time, and a resolution of $1024 \times 884$ pixels were used for the cathodoluminescence imaging.

Zircon grains were analyzed by the U-Pb isotopic technique using a SHRIMP IIe at CPGeo-USP following the analytical procedures of [40] and [41]. The crystals were mounted, together with the TEMORA-2 reference zircon [42], in epoxy and polished to expose the interior of the grains. The age of the TEMORA-2 reference zircon from this study was calculated at $416 \pm 31 \mathrm{Ma}$ (for sample ALTZ61) and $416 \pm 20 \mathrm{Ma}$ (for sample ALTZ68), which are indistinguishable within errors from its published age at $416.8 \pm 1.3$ Ma [42].

Grain ages within the concordance interval of $90-110 \%(206 \mathrm{~Pb} / 238 \mathrm{U}$ age $/ 207 \mathrm{~Pb} / 206 \mathrm{~Pb}$ age $\times 100$ ) (see [43]) were used for geochronological interpretation. Discordant analyses were generally interpreted with additional caution. Common $\mathrm{Pb}$ correction was based on the measured ${ }^{204} \mathrm{~Pb}$. The typical error for ${ }^{206} \mathrm{~Pb} /{ }^{238} \mathrm{U}$ ratios was less than $2 \%$. Uranium abundance and $\mathrm{U} / \mathrm{Pb}$ ratios were calibrated against the TEMORA-2 reference material, and the ages were calculated using Isoplot ${ }^{\circledR}$ version 4.15 software application [44]. Errors are reported as $1 \sigma$ deviations and ages have been calculated at the $95 \%$ confidence level.

\section{Results}

\subsection{Field Observations}

\subsubsection{Mafic Sheeted Dikes}

Three main tectonic slices of sheeted dike complexes were studied in detail along three rivers (or Assif in Amazigh language), providing the least weathered outcrops where individual dikes are clearly visible (Assif n'Tinzla, Assif n'Tasriwine, and Assif n'Iriri, Figures 2 and 3). They are separated by shear zones marked by mylonites and serpentinites with a general trend ranging between $N 70^{\circ}$ and $N 120^{\circ}$, a dip of $80^{\circ}$ to $90^{\circ}$ and a thickness 
ranging from 10 to $250 \mathrm{~cm}$ (Figure 5). These units appear to be heterogeneous and consist of sheeted dikes, gabbros and ultramafic rocks, plagiogranites, numerous hydrothermal veins, and a variety of faults and shear zones. Dikes in dike structures are rarely observed, but dikes correspond to about $50 \%$ or more of the volume of the units (see below). Some of the dikes display well-developed chilled margins.
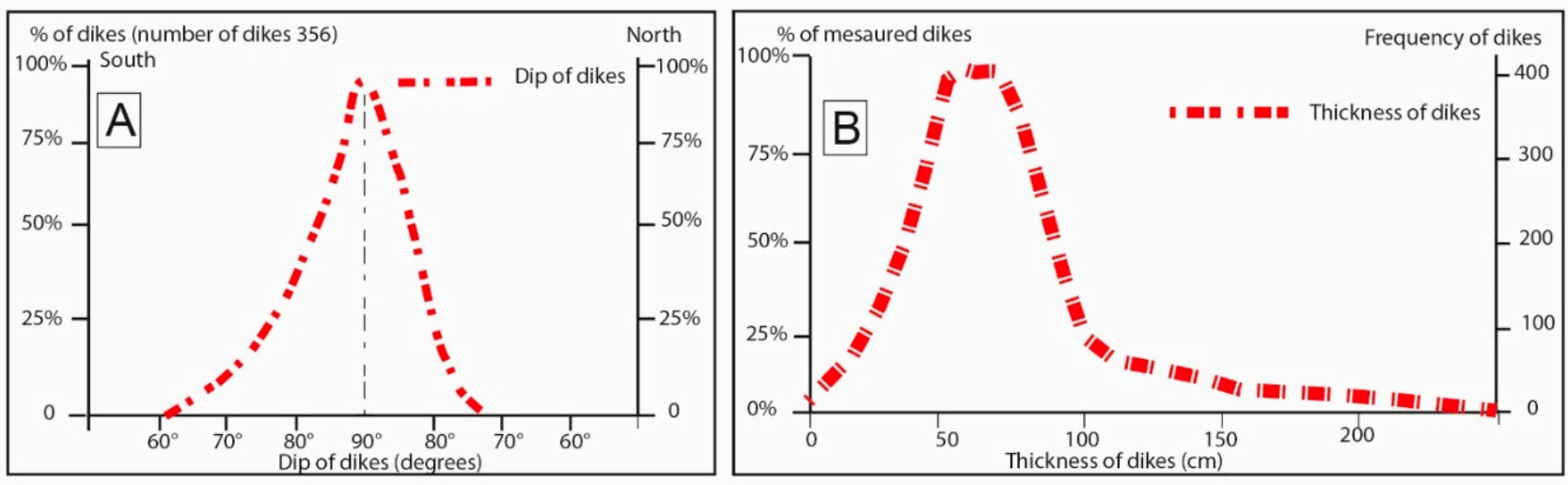

Figure 5. (A) Dip and (B) thickness of dikes from sheeted dike complex of the Khzama ophiolite.

To the west, along Assif n'Tinzla in the Amassine region (Figure 2), the sheeted dike complex shows weak deformation; the dike sets generally display vertical dips and strike $\mathrm{N} 70^{\circ}$ to $\mathrm{N} 90^{\circ}$ with a significant cluster striking $\mathrm{N} 80^{\circ}$ (Figure 6A). In this area and based on the measurement of the spacing and dike thicknesses, dikes occupy volumetrically $51 \%$, while the surrounding gabbros correspond to $49 \%$. The thicknesses of the dikes range from 10 to $250 \mathrm{~cm}$ with an important cluster between 30 and $40 \mathrm{~cm}$ (Figure 6B).

Along Assif n'Tasriwine in the Tourtit region (Figure 2), the sheeted dike complex is moderately deformed, displaying boudinage, elongation, folding and schistose fabric. The surrounding gabbros are mylonitized and amphibolitized (Figure 7B). The mean trend of the dikes is $\mathrm{N} 90^{\circ} \mathrm{E}$ in the northern part of this area whereas the dominant trend is $\mathrm{N} 120^{\circ} \mathrm{E}$ in the southern part (Figure $6 \mathrm{C}$ ). The dikes occupy $48 \%$ of the volume of this unit, against $52 \%$ of the surrounding gabbros. The thicknesses of the dikes in this area range from 10 to $150 \mathrm{~cm}$ (Figure 6D).

More to the east in the Tachakoucht region, along Assif n'Iriri (Figure 2), mylonitized rocks consist of: a) $\mathrm{N} 70^{\circ} \mathrm{E}$ striking dikes dipping $80^{\circ}$ to $90^{\circ}$ with thicknesses ranging from 10 to $200 \mathrm{~cm}$, exposed along $58 \%$ of the outcrop (Figure $6 \mathrm{E}$ ) and b) pyroxenite and pyroxenitic gabbro host rocks exposed along $42 \%$ of the outcrop. The thicknesses of the dikes range from 10 to $200 \mathrm{~cm}$ with a majority having values between 45 and $75 \mathrm{~cm}$ (Figure 6F).

The Tinzla River displays rhythmically alternating dikes and gabbros. A similar rhythmic gabbro/dikes sequence is also recognized in the Tasriwine area, where deformed, mylonitized and amphibolitized rocks occur (Figure 7A,B). The gabbro-dike contacts are highly irregular and frequently lobate (Figure $7 \mathrm{C}$ ). These field relations can be interpreted as syn-magmatic mingling. These contacts served as active ductile shear zones during the Pan-African orogeny. The dikes and gabbros show a centimetric lineation and foliation, the orientation of the latter in the flaser gabbro is sometimes oblique to the dikes margins indicating their emplacement along oblique fractures (Figure 7D). In Assif n'Tinzla the dike margins are oblique to gabbro magmatic foliation and the mylonitic texture. This obliquity indicates that a transpressional deformation affected the dikes. In Assif n'Tasriwine, we report the presence of megafaults, along which gabbros and dikes are strongly deformed and mylonitized, with dike-gabbro contacts evolving into highly tectonized shear zones. Amphibole fish-structures indicate sinistral movements within the shear zones. The intense deformation makes the relationship between the sheeted dike complex and the other units of ophiolites hardly recognizable. The sheeted dike complex of Khzama contains hydrothermal network veins that are generally parallel to the border of dikes and consist 
of epidote, quartz, chlorite and sulfide minerals (Figure 7D) [15,45]. These structures are comparable to those known in Oman ophiolite [46-50].
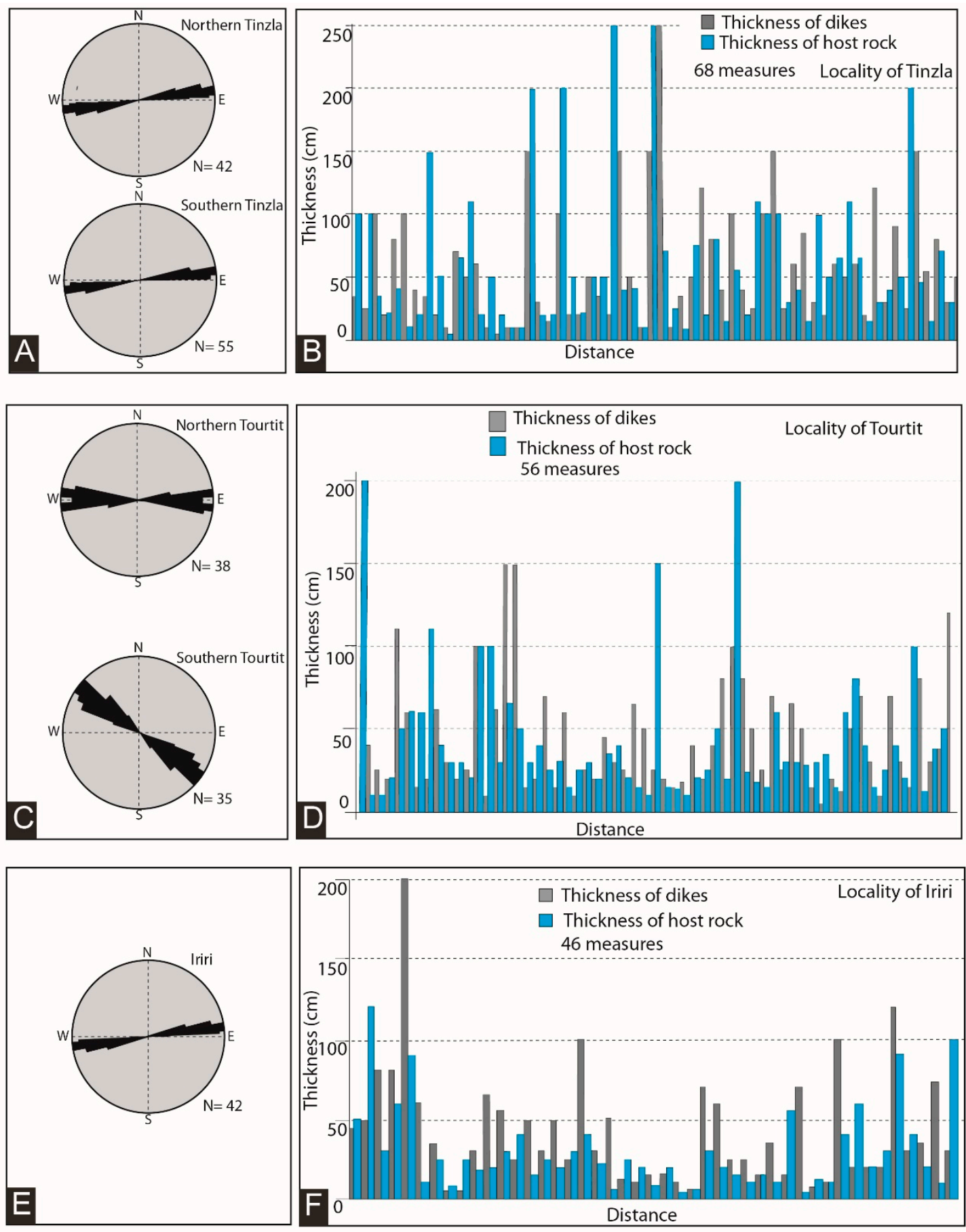

Figure 6. (A,C,E) Orientation and $(\mathbf{B}, \mathbf{D}, \mathbf{F})$ frequency of the sheeted dike complex of the Khzama ophiolite. Note that thicknesses of dikes in Tourtit area, where the sheeted dikes are highly mylonitized, may not represent their original thicknesses. 

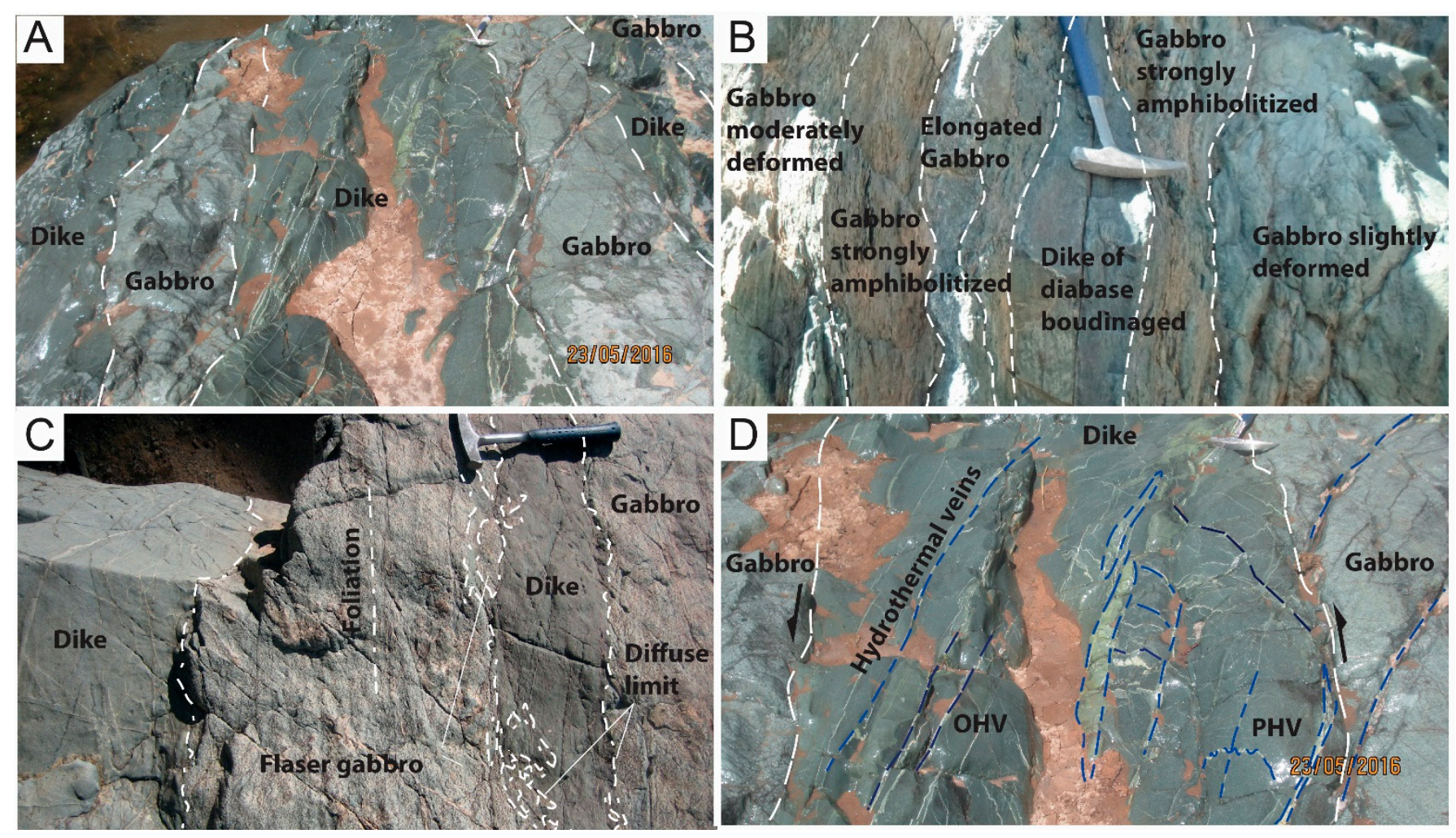

Figure 7. Field photographs of the sheeted dike complex of the Khzama ophiolite. (A) rhythmically alternating dikes and gabbros are exposed in Tinzla River, (B) A rhythmic gabbro/dike sequence in the Tasriwine area, intrude deformed, mylonitized and amphibolitized rocks, (C) The highly irregular gabbro-dike contact, (D) Hydrothermal network veins are oblique to the border of dikes in this outcrop. Abbreviations; $\mathrm{OHV}=$ oblique hydrothermal vein and $\mathrm{PHV}=$ parallel hydrothermal vein.

\subsubsection{Plagiogranites Dikes}

The plagiogranite and the felsic dikes, also called keratophyres in the area [13], are easily recognized in the field due to their leucocratic characteristics contrasting with the dominant melanocratic rocks. Plagiogranites intrude the upper crustal sequence of the Khzama ophiolite containing isotropic gabbros and the sheeted dike complex (Figure 4). The best outcrops of these rocks have been located mainly in the Adrar n'Tinzla valley and in the Assif n'Tasriwine valley. These intrusions usually occur as stocks, dikes and veinlets that are boudinaged and display gneissic banding, with a thickness ranging from $10 \mathrm{~cm}$ to $15 \mathrm{~cm}$ and an orientation of $\mathrm{N} \mathrm{80^{ \circ }}$ (Figure 8A,B). In the Tasriwine Assif valley the dikes are relatively thin and significantly deformed as evidenced by the development of a planar schistosity parallel to dikes directions. Plagiogranites sometimes show a co-mingling magmatic relationship with the gabbroic and diabasic host rocks (Figure 8C,D). 


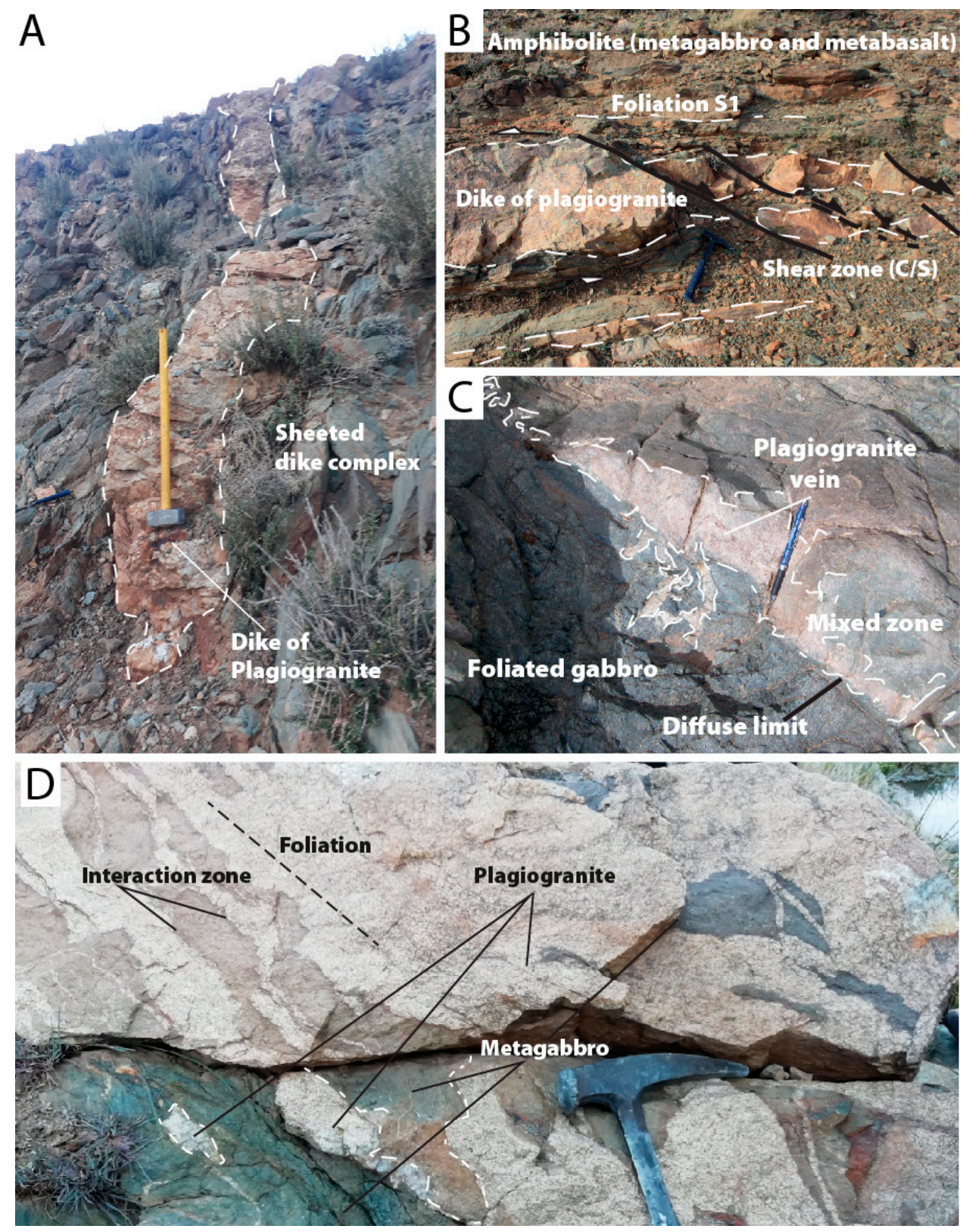

Figure 8. Field photographs of the plagiogranites of Khzama ophiolite: (A) Plagiogranite dike in Assif n'Tinzla; (B) Deformed dike of plagiogranite in Assif n'Tourtit; (C) Diffuse contact boundary between a plagiogranite vein and foliated gabbro in Tourtit River; and (D) breccias of metagabbro incorporated in a vein of plagiogranite of the Tourtit zone.

\subsection{Petrography}

\subsubsection{Mafic Sheeted Dikes}

The petrographic study of dolerite and plagiogranite of the sheeted dike complex, have been made for twenty samples collected from Assif n'Tinzla, Assif n'Tasriwine and Assif n'Tourtit. The metadoleritic sheeted dikes are melanocratic, medium grained in the center and fine grained towards the borders. Dike textures vary from doleritic (subophitic to intersertal) to aphanitic (Figure 7). In Assif n'Tinzla, the primary magmatic textures of dikes and surrounding gabbros are generally preserved with relics of primary paragenesis (pyroxene, plagioclase and hornblende) (Figure 9A). In Assif n'Tasriwine, where the dikes and gabbros (Figure 9B) are highly foliated, boudinaged foliated (Figure 7C) and totally amphibolitized and chloritized, the texture is granoblastic and grano-nematoblastic to lepidoblastic with a planar fabric. 

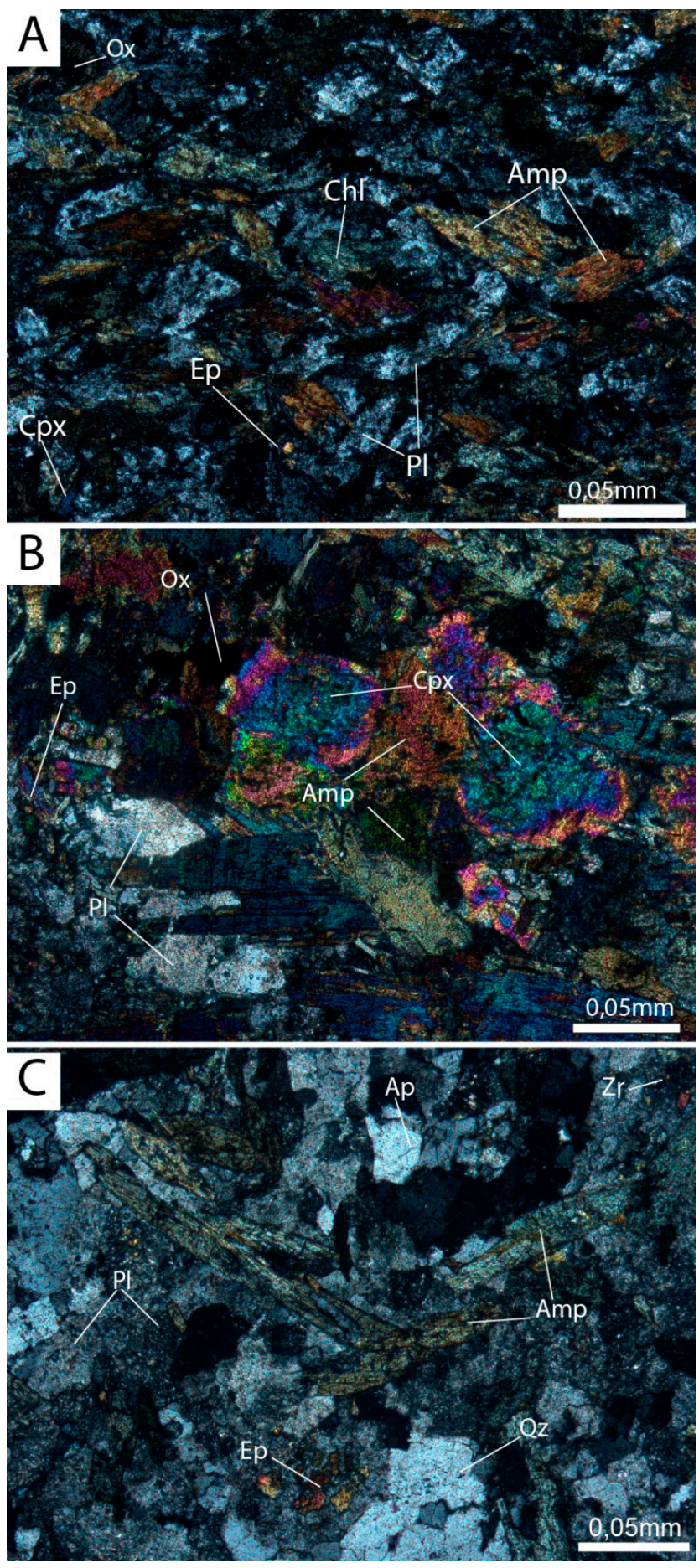

Figure 9. Thin section photomicrographs of the studied rocks of Khzama Ophiolite. (A) Mafic dike from the sheeted dike complex. The primary mineralogy contains plagioclase ( $\mathrm{Pl})$, clinopyroxene $(\mathrm{CPx})$, and oxides (Ox). The secondary phase is formed by amphibole (Amph), chlorite (Chl), epidote (Ep), quartz (Qz), and oxides (Ox); crossed nicols. (B) The dated leucogabbro with a mineralogy consisting of clinopyroxene ( $\mathrm{CPx})$ partially transformed to amphibole (Amp) and plagioclase ( $\mathrm{Pl})$ as primary minerals. The secondary minerals are amphibole (Amp) and epidote (Ep); crossed nicols. (C) The dated plagiogranite with primary minerals of plagioclase $(\mathrm{Pl})$, quartz $(\mathrm{Qz})$, zircon $(\mathrm{Zr})$, and apatite (Ap). The secondary minerals consist mainly of amphibole (Amp) and epidote (Ep); crossed nicols. 
Metadolerites consist mainly of pyroxenes, amphiboles, plagioclase, and oxides. These minerals are set in a groundmass of quartz-albite which indicates a sub-alkaline composition. They are partly replaced by secondary minerals that include epidote and chlorite. Pyroxene (augite) generally has a fine grain diameter of 0.1 to $0.5 \mathrm{~mm}$ and occurs as isolated crystals in the groundmass or as inclusions within amphiboles. Plagioclase crystals with diameters between 0.1 and $1.5 \mathrm{~mm}$ constitute about $40 \%$ of the groundmass. These plagioclase crystals are transformed into epidote, chlorite, albite and quartz. Amphibole minerals have mainly actinolitic hornblende and tremolite composition and show alteration along their rims.

\subsubsection{Plagiogranite Dikes}

Plagiogranites (Figure 9C) present fine- to medium-grained hypidiomorphic textures with common myrmekitic intergrowths of vermicular quartz and plagioclase as is typical of such rocks. These rocks are mainly composed of quartz, plagioclase and very rare biotite disposed in mosaic arrangements. These rocks are composed mainly of quartz, plagioclase and very rare biotite. Apatite and zircon occur as accessory minerals. K-feldspar is rarely observed. Secondary minerals are mainly chlorite. In the areas where dikes are mylonitized, they are locally invaded by veinlets of secondary amphiboles, oxides and epidotes. Based on the low proportion of mafic minerals and according to their molecular normative AnAb-Or (anorthite-albite-orthoclase) composition, the studied plagiogranites are classified as trondhjemites [51].

\subsection{Geochemistry}

\subsubsection{Mafic Sheeted Dikes}

Despite the moderately low values of LOI $(\leq 3.5 \mathrm{wt} \%$; see Table 1$)$ suggestive of only moderate to low alteration (s.l.) (see also Section 4.2), the geochemical features of the mafic dikes, belonging to Khzama ophiolites in the Siroua inlier, are described using whole-rock major and trace elements considered virtually immobile during meteoric alteration and low-grade metamorphism.

Sheeted dikes are basaltic to andesitic in composition, displaying a clear sub-alkaline nature, as exemplified by their low $\mathrm{Nb} / \mathrm{Y}$ ratios $(<1)$ (Figure 10). Based on their $\mathrm{TiO}_{2}$ contents, two groups of mafic dikes can be distinguished $\left(\mathrm{TiO}_{2}>2.1 \mathrm{wt} \% ; \mathrm{TiO}_{2}<1.2 \mathrm{wt} \%\right)$, which cannot be considered the result of different degrees of fractionation from a common parental magma. Indeed, such distinction is possible even for samples being similarly evolved, i.e., displaying similar differentiation index such as $\mathrm{FeO} / \mathrm{MgO}$ and $\mathrm{Ti} / \mathrm{Y}$ (Figure 11A,B; Table 1). These two groups are also distinguished based on their REE patterns (Figure 12A) which depict a clearly more enriched composition for the High-Ti Group (e.g., $\mathrm{La}-\mathrm{Lu}=38.8$ to 65.4) than for the Low-Ti dike Group (La-Lu = 2.1 to 27.4). The analyzed leucogabbros display lower REE content compared to the two dike groups with a nearly flat REE pattern that is about 3 times richer than chondrites (Figure 12A). 


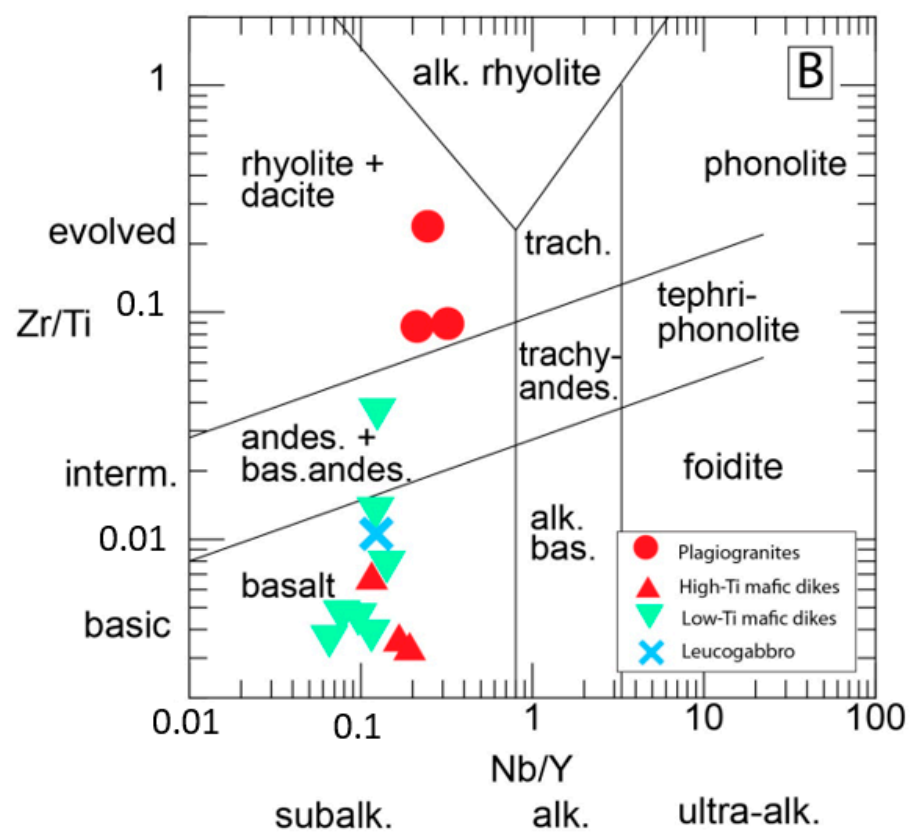

Figure 10. Zr/Ti vs. Nb/Y classification diagram for the Khzama sheeted dikes [52] after [53].
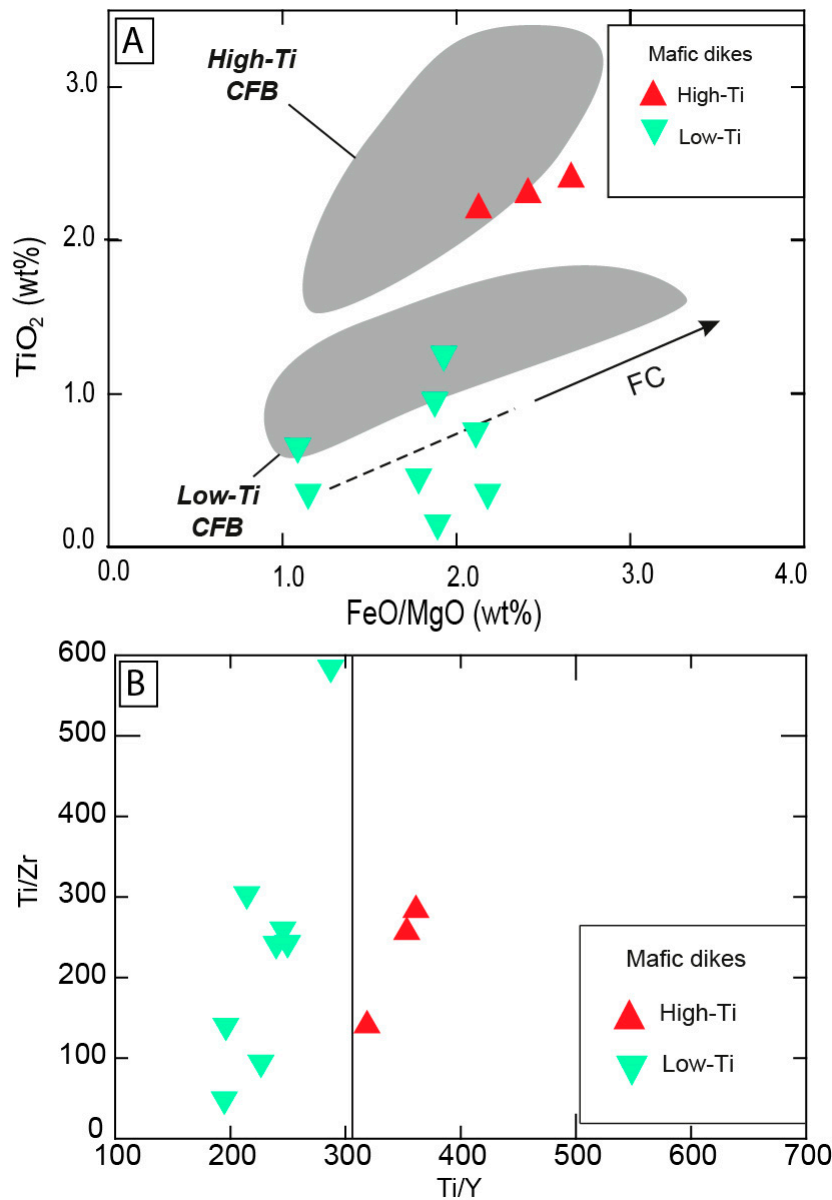

Figure 11. (A) $\mathrm{TiO}_{2}$ as a function of the $\mathrm{FeO} / \mathrm{MgO}$ ratio for the tholeiitic Continental Flood Basalt Group (CFB Group) of the mafic dikes of sheeted dike complex from the Khzama ophiolite (Anti-Atlas, Morocco). FeO/MgO ratio is used as the index of differentiation; FC = Fractional Crystallization. CFB fields for comparison from [54] after [55]. (B) Ti/Y vs. Ti/Zr: low-Ti magma types arc distinguished from High-Ti magma types by low Ti/Y $(<310)$ in the Parana-Etendeka Province after [56]. 

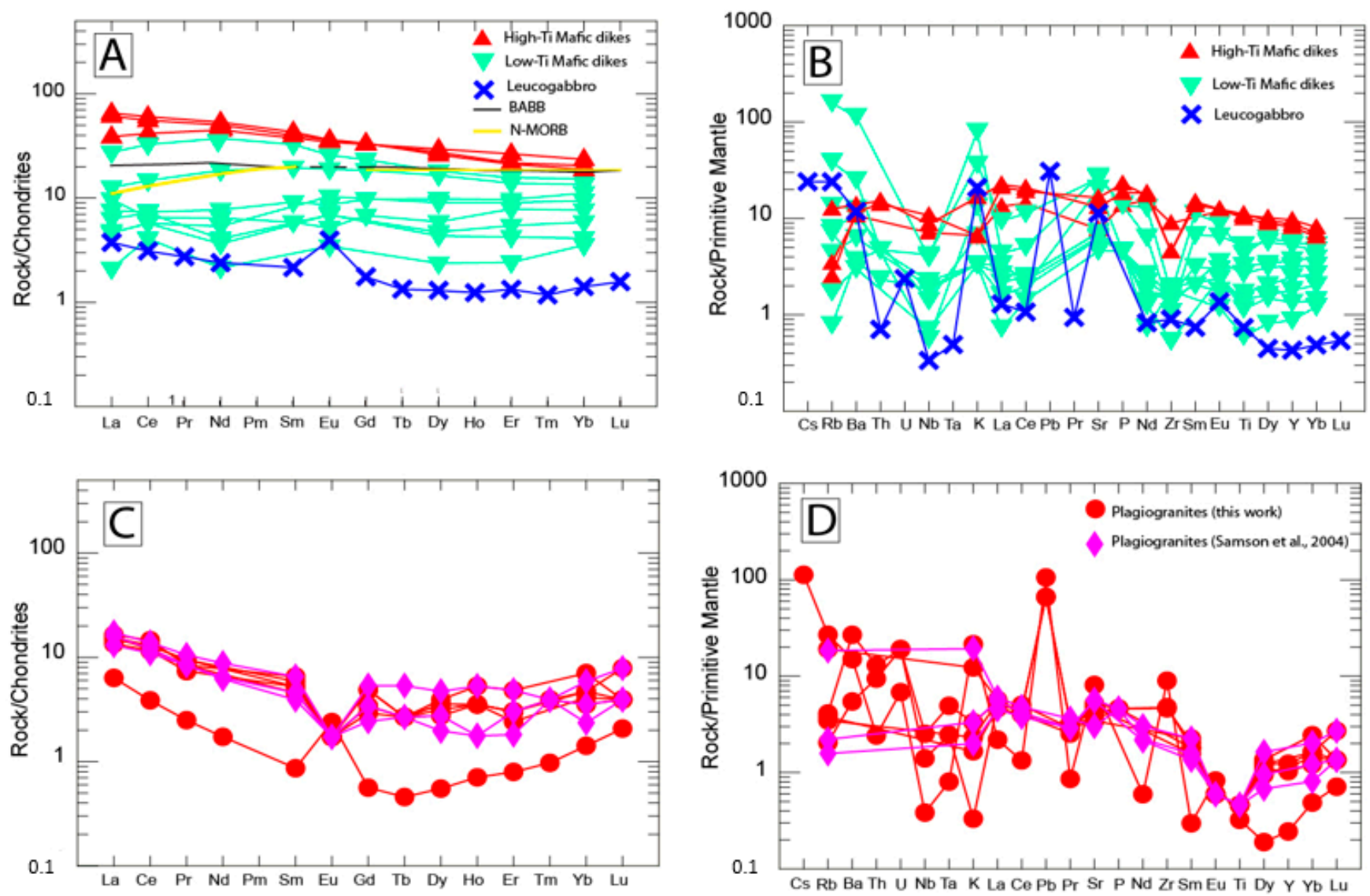

Figure 12. (A,C) Masuda-Coryell normalized plots for rare-earth elements in mafic and felsic intrusive rocks of the Khzama ophiolite. Chondrite values used for normalization are from [57]. The average N-MORB and BABB patterns are used for comparison [58]. (B,D) Primitive mantle-normalized trace element 'spidergram' for the mafic and the felsic intrusive rocks of the Khzama ophiolite and the plagiogranitic analysis of [22] are used for comparison. Primitive mantle values used for normalization are from [57].

The low-Ti basalt Group and the leucogabbro show significant depletion in $\mathrm{Nb}$ compared to the High-Ti Group of dikes (Figure 12B). Finally, it is worth mentioning that the dated "leucogabbro" displays a pronounced positive Eu anomaly (Figure 12A) testifying to the accumulation of plagioclase.

\subsubsection{Plagiogranites Dikes}

Plagiogranites are characterized by low LOI values $(<1.3 \mathrm{wt} \%)$ allowing the use of the alkali's concentrations for their characterization. These rocks plot in the rhyodaciterhyolite fields of the diagram from Figure 10. They have consistently high $\mathrm{SiO}_{2}(>76 \mathrm{wt} \%)$ which would classify them as rhyolites according to the TAS diagram (not shown). They have $\mathrm{Na}_{2} \mathrm{O}(>12 \mathrm{wt} \%)$ and extremely low $\mathrm{K}_{2} \mathrm{O}(<0.7 \mathrm{wt} \%)$ contents (Table 1$)$. The $\left(\mathrm{K}_{2} \mathrm{O} \times\right.$ $100) /\left(\mathrm{Na}_{2} \mathrm{O} \times \mathrm{K}_{2} \mathrm{O}\right)$ ratio ranging from 0.1 to 4.9 is typical of oceanic plagiogranites [59-62]. Plotting normative $\mathrm{Or}, \mathrm{An}$, and $\mathrm{Ab}$ from these rocks on a ternary diagram (Figure 13A) reveals that they all fall within the trondhjemite domain defined by [51], which is also consistent with their peraluminous character $\left(\mathrm{Al}_{2} \mathrm{O}_{3}>12.5 \mathrm{wt} \%\right.$, except for one sample (sample AHTZ7) with $12.10 \mathrm{wt} \%$; $\mathrm{A} / \mathrm{CNK}\left[\mathrm{A} / \mathrm{CNK}=\right.$ molar ratio $\mathrm{Al}_{2} \mathrm{O}_{3} /\left(\mathrm{CaO}+\mathrm{Na}_{2} \mathrm{O}\right.$ $+\mathrm{K}_{2} \mathrm{O}$ )] = 1.2-1.4; e.g., [63] (Figure 13B). Thus, they can be classified as high silica-low alumina trondhjemites. As is typical from plagiogranites the studied rocks are characterized by low $\mathrm{Rb}(<3 \mathrm{ppm}$ ) and $\mathrm{Rb} / \mathrm{Sr}$ ratios lower than 0.015 (cf. [60]). The two samples that show $\mathrm{Rb}$ content higher than $5 \mathrm{ppm}$ and $\mathrm{Rb} / \mathrm{Sr}$ ratios in excess of 0.015 likely experienced interactions with external hydrothermal fluids with clearly different chemistries [60]. Chondrite-normalized REE patterns of the studied plagiogranites (Figure 12C) shows 
moderate enrichment ( $\mathrm{La}_{\mathrm{n}}$ up to 16.4) and concave upwards patterns, i.e., with depleted MREE vs. LREE $((\mathrm{La} / \mathrm{Sm}) \mathrm{n}=2.5-7.4)$ and HREE $((\mathrm{Gd} / \mathrm{Lu}) \mathrm{n}=0.3-1.2)$. Except for the sample ALTZ68, they are characterized by negative Eu anomaly; indicating removal of plagioclase by crystal fractionation and/or that they not represent partial melts that left plagioclase in the residue melting (Figure 12C,D). The multi-element spider diagram of most plagiogranite samples normalized to primitive mantle shows negative $\mathrm{Nb}$ and $\mathrm{Ti}$ anomalies and positive anomalies in $\mathrm{Pb}$ and Th (Figure 12D).
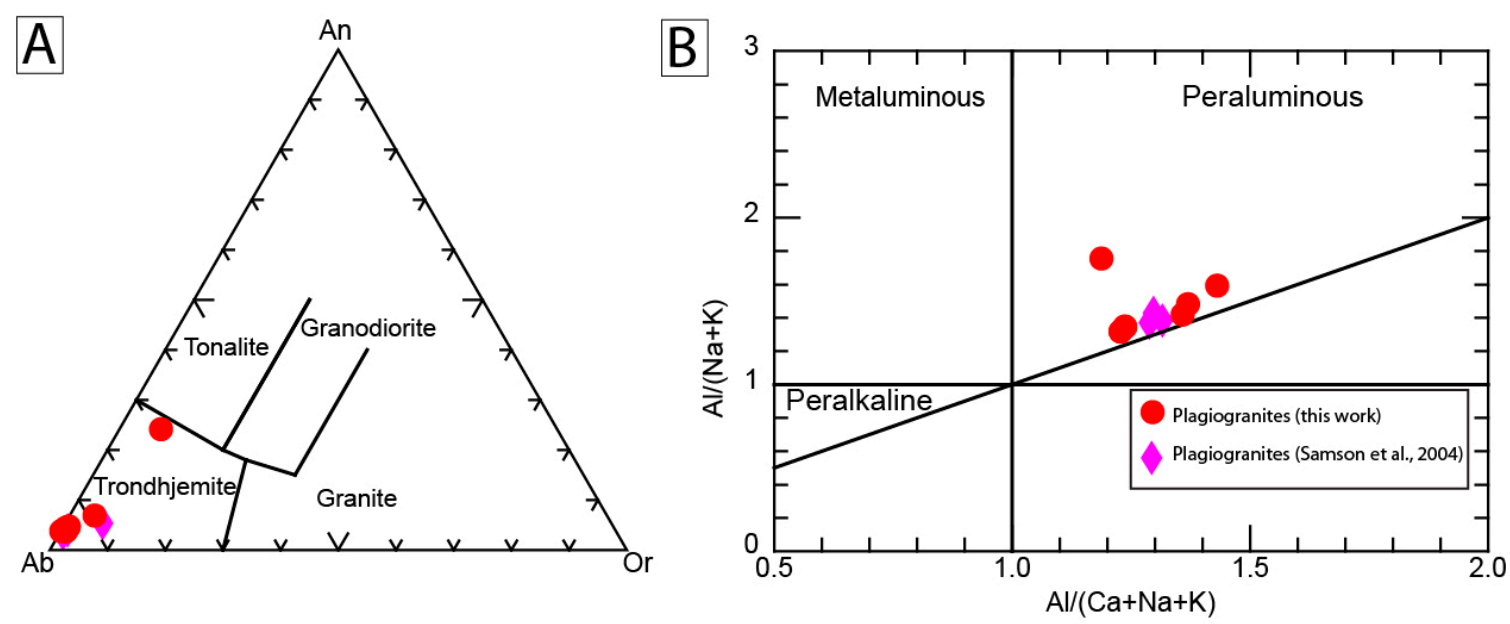

Figure 13. (A) Classification and nomenclature of the Khzama ophiolite plagiogranites based on the normative An- $\mathrm{Ab}-\mathrm{Or}$ diagram (after [51]). (B) Plots of the Khzama ophiolite Plagiogranites in Molar A/CNK [A/CNK $=$ molar ratio $\mathrm{Al}_{2} \mathrm{O}_{3} /(\mathrm{CaO}$ $+\mathrm{Na}_{2} \mathrm{O}+\mathrm{K}_{2} \mathrm{O}$ ) and $\mathrm{A} / \mathrm{NK}=$ molar ratio $\mathrm{Al}_{2} \mathrm{O}_{3} /\left(\mathrm{Na}_{2} \mathrm{O}+\mathrm{K}_{2} \mathrm{O}\right)$ ] (after [63]) analysis of [22] plagiogranites are used for comparison.

\subsection{U-Pb Geochronology}

\subsubsection{Ophiolitic Leucogabbro: Sample ALTZ61}

Euhedral to subhedral zircon grains from the sample ALTZ61 (leucogabbro) exhibit mean lengths and widths of 114 and $43 \mu \mathrm{m}$, respectively. Cathodoluminescence (CL) images show oscillatory zoning throughout most of the grains (Table S1 and Figure 14). A portion of grains show overgrowths by luminescent rims while other grains show overgrowths of continuous non-luminescent rims. The oscillatory zoned cores and the luminescent rims represent igneous growth while the continuous non-luminescent rims may represent a hydrothermal overgrowth. The Th/U ratio ranges from 0.24 to 0.88 , suggesting an igneous origin of the oscillatory zoned cores and the luminescent rims (e.g., [64,65]). Seventeen spots were analyzed on 15 grains (Table S1 and Figure 15A). All analyses that overlap within errors with the mean age of the youngest grain (i.e., $761 \mathrm{Ma}$, analyses 15.1, 4.1, 3.1, 11.1) were used to calculate the age of gabbro crystallization at $763 \pm 5 \mathrm{Ma}$ (MSWD of concordance $=0.47$, Probability of concordance $=0.49$ ), while analyses that overlap within errors with the age of the grain that is older directly than the previous population (i.e., $777 \mathrm{Ma}$, analyses $1.1,2.1,7.1,9.1,10.1,12.1,13.1,14.1)$ yielded a mean ${ }^{206} \mathrm{~Pb} /{ }^{238} \mathrm{U}$ age at $784 \pm 7 \mathrm{Ma}$ (MSWD of concordance $=0.45$, Probability of concordance $=0.87$ ). Two concordant spots yielded a mean inherited ${ }^{206} \mathrm{~Pb} /{ }^{238} \mathrm{U}$ age at $802 \pm 12 \mathrm{Ma}$ (MSWD of concordance $=0.037$, Probability of concordance $=0.85$ ) while two spots analyzed on two xenocores have inherited ${ }^{206} \mathrm{~Pb} /{ }^{238} \mathrm{U}$ ages of $866 \pm 15$ and $922 \pm 16 \mathrm{Ma}$. The significance of these ages is discussed later (see section discussion). 


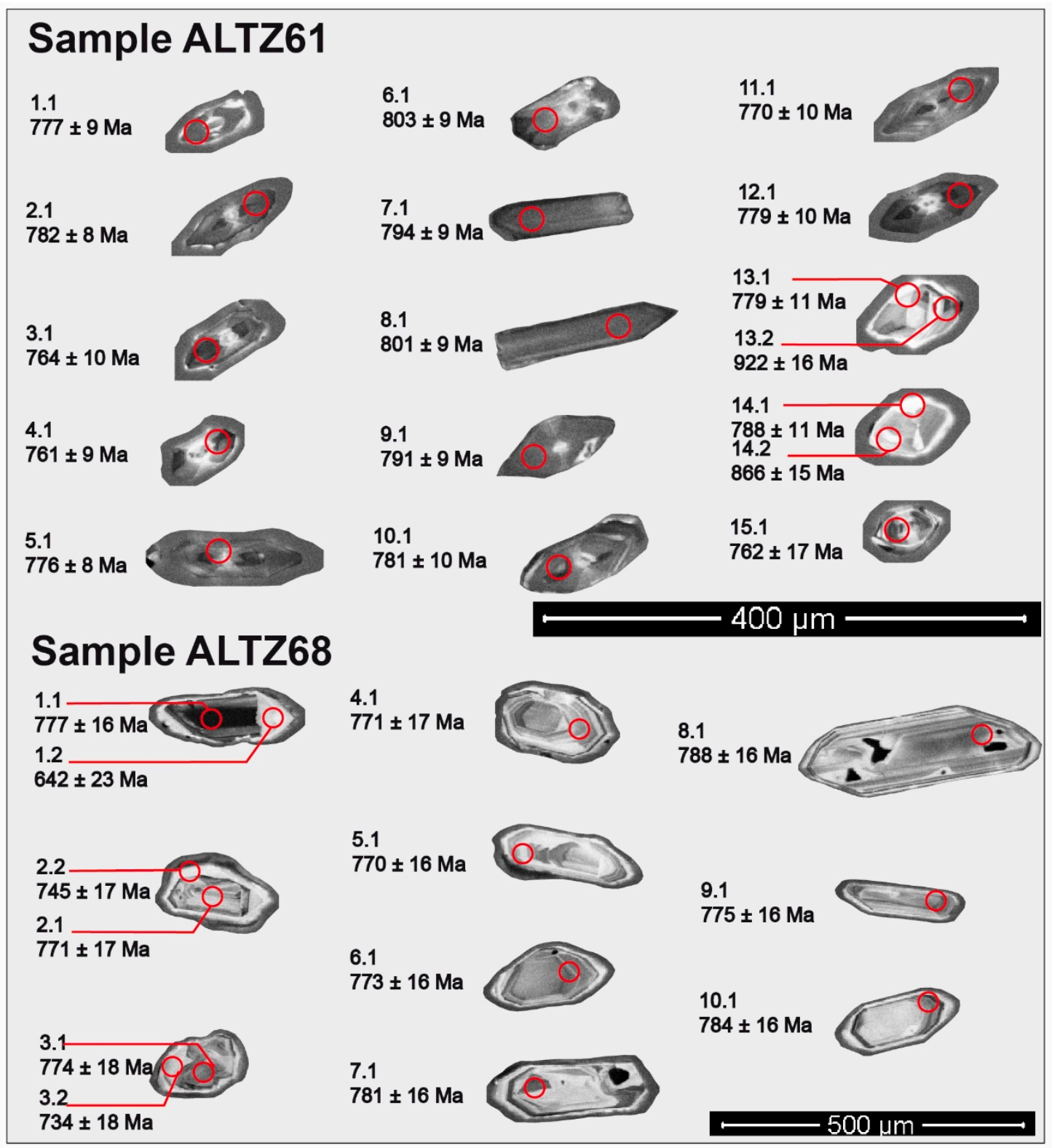

Figure 14. Cathodoluminescence (CL) images of zircon grains obtained from the samples ALTZ61 and ALTZ68 showing their internal texture, spots (red circles), and apparent ${ }^{206} \mathrm{~Pb} /{ }^{238} \mathrm{U}$ ages in $\mathrm{Ma}(1 \sigma$ error). 
data-point error ellipses are $68.3 \%$ conf.

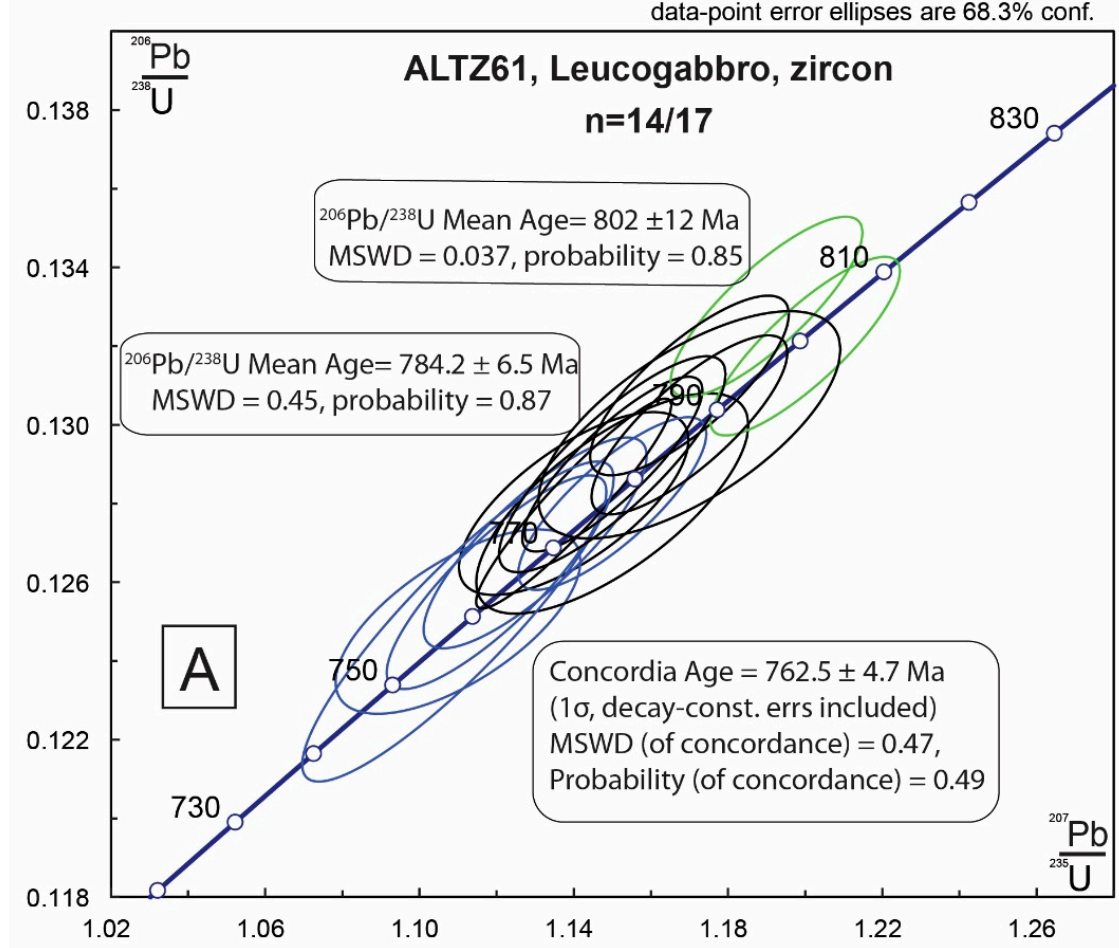

data-point error ellipses are $68.3 \%$ conf.

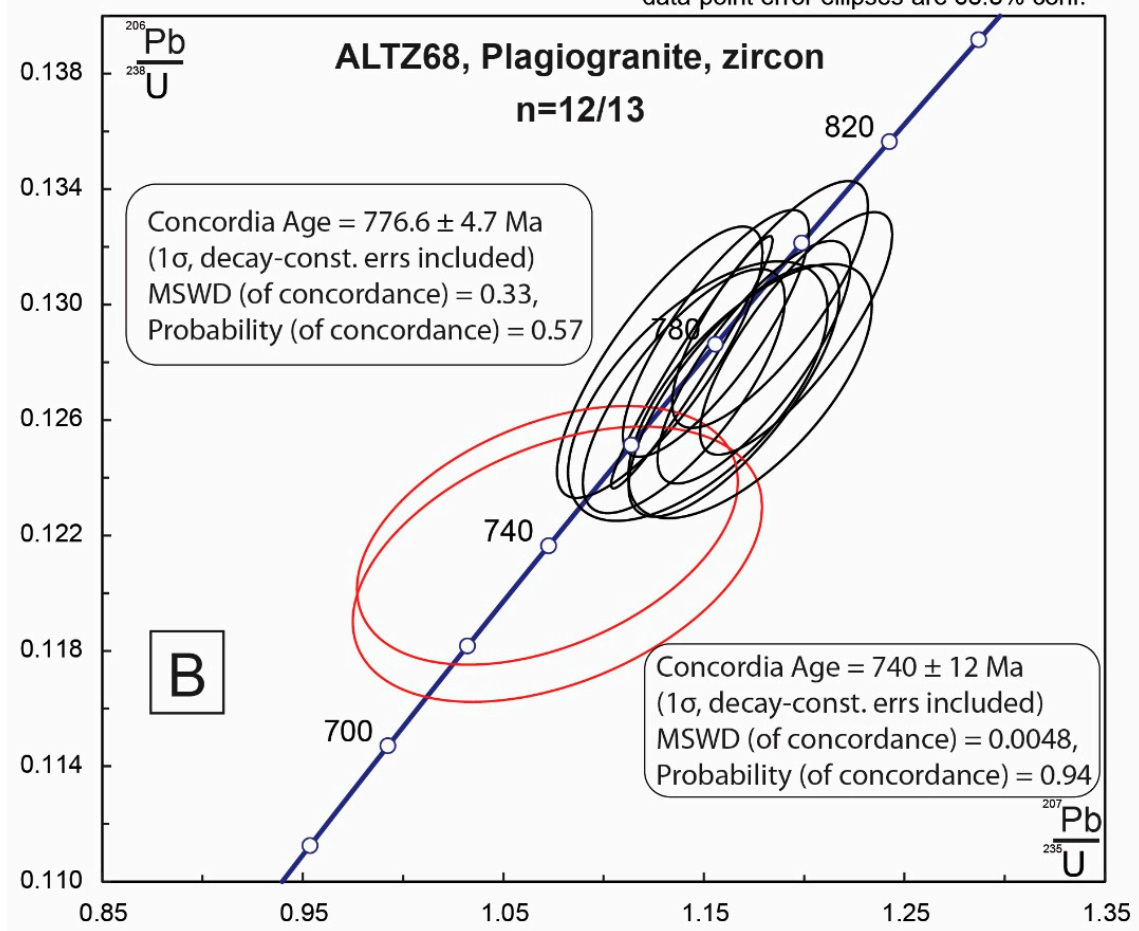

Figure 15. Zircon U-Pb SHRIMP geochronology; Wetherill concordia plots of U-Pb zircon data for (A) the leucogabbroic sample ALTZ61 and (B) the plagiogranite sample (ALTZ68) of the Khzama ophiolite.

\subsubsection{Plagiogranite Dike: Sample ALTZ68}

Euhedral to subhedral zircon grains, from sample ALTZ68, exhibit mean lengths and widths of 242 and $97 \mu \mathrm{m}$, respectively. Cathodoluminescence (CL) images show oscillatory zoned cores overgrown by more luminescent, than non-luminescent rims (Table S2 and Figure 14). The zircon cores can be interpreted as igneous growth reflecting crystallization of the plagiogranite magma. The non-luminescent overgrowths are interpreted as possible 
hydrothermal growth, while the luminescent rims could have originated from a second metamorphic or magmatic event. However, the Th/U ratio ranges from 0.19 to 0.95 , indicating a population of probable igneous origin possibly crystallized from magmas of intermediate to felsic composition (e.g., [64,65]. Thirteen spots were analyzed on 10 grains (Table S2, Figure 15B). The spots used to calculate the resulting age data were generally taken from oscillatory zoned regions of the grains. Nine spots yielded a concordant age of $777 \pm 4.7 \mathrm{Ma}$ (MSWD of concordance $=0.33$, Probability of concordance $=0.57$ ) interpreted as the crystallization age of the plagiogranite while two spots analyzed on the luminescent overgrowths gave a concordia age of $740 \pm 12 \mathrm{Ma}$ (MSWD of concordance $=$ 0.0048; Probability of concordance $=0.94$ ) that could be the age of a metamorphic event recorded in the Siroua window.

\section{Discussion}

\subsection{Tectonomagmatic Setting of the Khzama Ophiolite}

In order to decipher the tectonomagmatic setting of the studied mafic (leucogabbro and mafic dikes) and felsic rocks and consequently the tectonomagmatic setting of Khzama ophiolite, immobile elements diagrams based were used. The immobile elements that are usually used for such purpose comprise: $\mathrm{Ti}, \mathrm{P}, \mathrm{Zr}, \mathrm{Y}, \mathrm{Nb}, \mathrm{Ta}, \mathrm{Hf}$, Th, middle and heavy REE, as well as some transition metals (e.g., $\mathrm{Ni}, \mathrm{Co}, \mathrm{Cr}, \mathrm{V})$ (e.g., [66-76].

The lithologic and structural study of the Bou-Azzer Group, and particularly of the Siroua inlier, clearly support the hypothesis that they represent fragments of dismembered ophiolite(s), thus pointing to an oceanic setting for the generation of their magmatic rocks. However, mafic rocks from the Siroua inlier (Khzama ophiolite) plot above the MORB-OIB array on the $\mathrm{Nb} / \mathrm{Yb}$ vs. Th/Yb diagram (Figure 16A). Considering the above mentioned oceanic (s. 1.) setting such deviation of that array cannot be assigned to crustal contamination a process that would increase the Th content and $\mathrm{Th} / \mathrm{Yb}$ of contaminated magmas owing the Th-rich composition of the continental crust [77] (see below for a discussion on the absence of significant crustal contamination). In this perspective such relatively high $\mathrm{Th} / \mathrm{Yb}$ value for a given $\mathrm{Nb} / \mathrm{Yb}$ value must be assigned to supra-subduction setting of the mantle source (e.g., [78]).
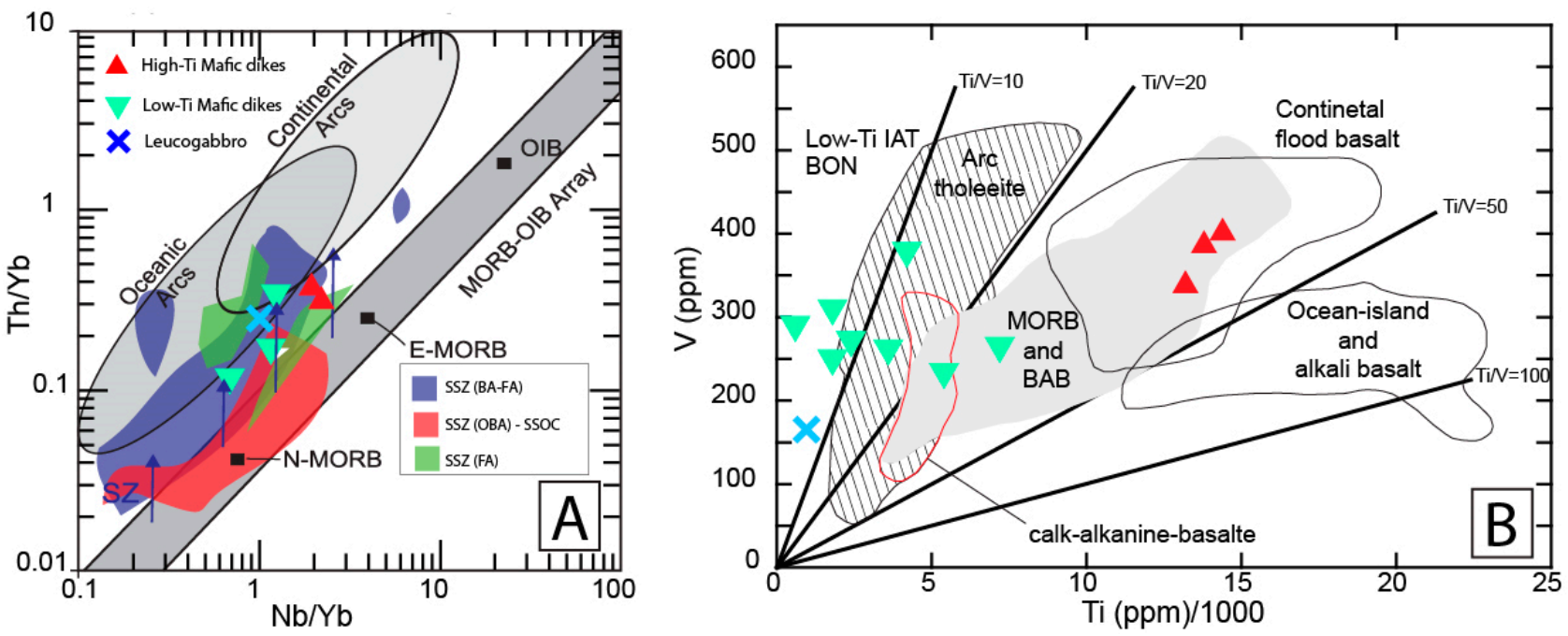

Figure 16. (A) The Ta/Yb vs. N/Yb ratio diagram [79]. The $\mathrm{Th} / \mathrm{Nb}$ proxy is used to distinguish a suprasubduction zone (SSZ) ophiolites from those of mid-ocean ridge. Mafic rocks analysis from suprasubduction-zone (SSZ) ophiolite types [backarc-forearc (BA-FA), forearc (FA), continental backarc (CBA), and oceanic backarc (OBA)] are presented from [37] for comparison (B) The Ta/Yb vs. Th/Yb ratio diagram suggested by [80], and improved by [6]. According to [79], the V/Ti subduction-melting proxy is useful to distinguish island arc tholeiite (IAT), MORB and boninite magma types. 
Given the water fluxing resulting from the dehydration of the subducting slab, the mantle wedge is usually characterized by high oxygen fugacity, which may constrain the behavior of some elements during subsequent melting events. It is the case of vanadium which normally behaves like the other transition elements, but this element is present on its oxidized species $\left(\mathrm{V}^{4+}\right.$ and $\left.\mathrm{V}^{5+}\right)$ under high oxygen fugacity conditions, becoming incompatible with pyroxene. This explains why the Ti/V ratios of mafic supra-subduction magmas are lower than those observed in non-subduction-related magmas (e.g., [70]). In Figure $16 \mathrm{~B}$ it becomes evident that most of the Low-Ti dikes are characterized by Ti/V ratios below 20, which confirms a supra-subduction zone geodynamic setting of the Khzama ophiolite rocks [81-84]. Some of these Low-Ti mafic dikes are even characterized by $\mathrm{Ti} / \mathrm{V}$ ratios lower than 10, typical of boninite-type rocks, which, according to [85,86] and [79], are the first products of arc magmatism.

The Low-Ti dike Group is also characterized by strong negative $\mathrm{Nb}$ anomalies, which is a characteristic property of the rocks found in island arc suites. It is generally believed to result from the lack of fusion of HFSE bearing phases, such as rutile, or to the insolubility of $\mathrm{Nb}$ (and $\mathrm{Ta}$ ) in hydrous fluids resulting from slab dehydration in shallow parts of a subduction zone [87].

On the contrary, the High-Ti dikes are characterized by significantly higher Ti/V $(>30)$ values, similar to those of MORB and backarc basin basalts [70]. High-Ti dykes are also distinguished by the relative absence of $\mathrm{Nb}$ negative anomalies (Figure 12B) that makes them different from island arc basalts, but compatible with a backarc setting [88]. The leucogabbro and the plagiogranites are also characterized by negative $\mathrm{Nb}$-Ta anomalies (Figure 12D). Low-Ti mafic dikes, leucogabbro and plagiogranites are all characterized by high LILE/HFSE ratios typical of supra-subduction settings (e.g., [89]).

On the $\mathrm{Ba} / \mathrm{Zr}$ ratio vs. $\mathrm{Nb} / \mathrm{Zr}$ ratio diagram of Ishizuka et al. [90], most of the Low-Ti mafic dikes plot within the backarc basin basalt (BABB) and the island arc basalt fields (Figure 17). The High-Ti mafic dikes of the sheeted dikes plot mostly near the average enriched-type mid-ocean ridge basalt (E-MORB) field.

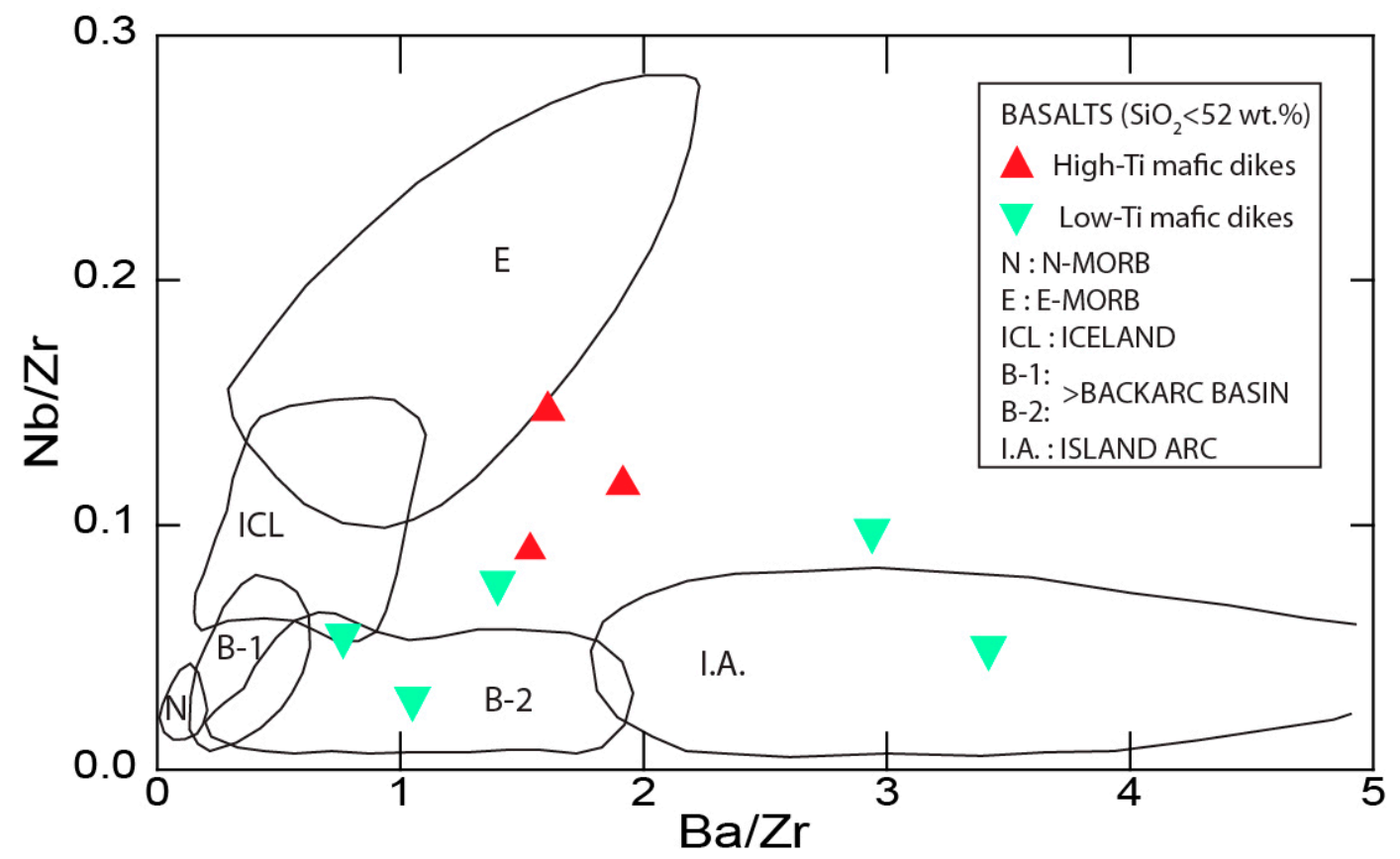

Figure 17. Bulk rock analyses of the Khzama ophiolite mafic dikes plotted in the $\mathrm{Nb} / \mathrm{Zr}-\mathrm{Bal} \mathrm{Zr}$ diagram of [90]. For compositional ranges of N-MORBs, E-MORBs, Iceland basalts, B-I (inactive BAB basalts), B-2 (active BAB basalts), and island arc basalts see [90] and references therein. 
It must be noticed that the depletion in $\mathrm{Nb}$, the relatively high LILE/HFSE ratios, the low $\mathrm{Ti} / \mathrm{V}$ ratios, and the high $\mathrm{Th} / \mathrm{Yb}$ for a given $\mathrm{Nb} / \mathrm{Yb}$ could be all explained by crustal contamination of mafic magmas [91], given that continental crust grows at subduction zones by mass transfer from the mantle. Crustal contamination of mafic magmas arose from the significantly different solidus temperatures between mafic and intermediate/felsic compositions prompting the melting of crustal domains in contact/proximity with mafic magmas. Moreover, crystallization is an exothermic process and the melting and assimilation of crustal rocks by mafic magmas is usually accompanied by crystallization, the AFC (assimilation, and fractional crystallization) and the EC-AFC (energy-constrained assimilation and fractional crystallization) processes [92]. In such processes, the effects of crustal contamination become more evident with the advancing of magmatic evolution. This is not the case of the studied samples where, for example, no significant correlation

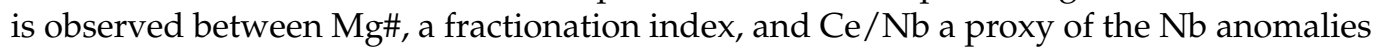
(Figure 18); these analytical results point to an insignificant importance of crustal contamination affecting the composition of the Khzama ophiolite at the Siroua inlier.

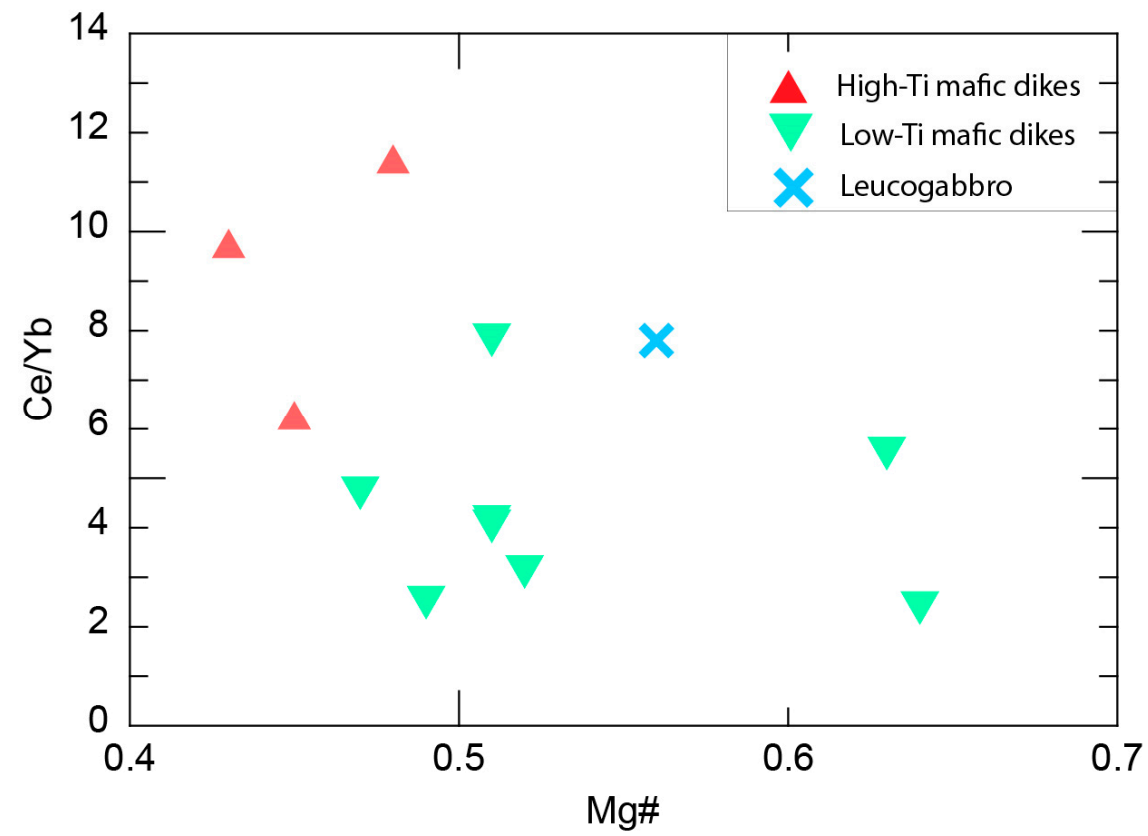

Figure 18. Plots of $\mathrm{Ce} / \mathrm{Nb}$ vs. $\mathrm{Mg} \#$ for the mafic rocks of this study.

Considering all the geochemical characteristics and the above discussion, it appears most likely that the Khzama ophiolite was emplaced in a backarc setting with variable input of LILE enriched slab-derived fluids. This suggests that the studied mafic rocks are genetically linked to magmas sourced from a supra-subduction mantle wedge and affected by recycled crustal components derived from the subducting slab [71,93-95].

\subsection{Assessing Magma Genesis and Evolution}

The source and the depth of magma genesis can be evaluated using the $\mathrm{Ce} / \mathrm{Yb}$ ratio of basaltic rocks. When the $\mathrm{Ce} / \mathrm{Yb}$ ratio is high, it can be an indication of garnet in the source residue since garnet has low partition coefficients for Ce but high for $\mathrm{Yb}$ [96-98]. Therefore, partial melts originated from garnet peridotites will have comparatively high $\mathrm{Ce} / \mathrm{Yb}$ ratios (>20; [99]). On the other hand, partial melting of spinel peridotites produces no residual phase that confiscates the HREE, resulting in melts with relatively lower $\mathrm{Ce} / \mathrm{Yb}$ ratios. The studied mafic rocks (mafic dikes and the dated leucogabbro) show a low $\mathrm{Ce} / \mathrm{Yb}$ (2.3-11.6) suggestive of a spinel peridotite source.

The evaluation of the relative importance of fractional crystallization and partial melting on the variability of the studied rocks can be made using diagrams with the 
incompatible element Th as an index of differentiation versus compatible elements such as Sc, Ni, Cr and Co [80,100-103], Figure 19A-D show moderate variations in Th contents for the studied mafic rocks, while an insignificant variation is observed for $\mathrm{Sc}, \mathrm{Ni}, \mathrm{Cr}$ and Co contents indicating a less significant control by fractional crystallization rather than partial melting processes. In the absence of isotopic signatures (e.g., ${ }^{143} \mathrm{Nd} /{ }^{144} \mathrm{Nd}$ ), it is not possible to decide if the larger variation on Ce is reflecting source heterogeneities or differences on extent of melting. Two contrasting models have been considered to explain the origin of oceanic plagiogranites (see [104]; and references therein): (i) extreme fractional crystallization of a mantle-derived magma; (ii) hydrous partial melting of basic oceanic crust rocks. The possible role of each of these models was experimentally assessed [105]. The rocks in this study plot on or very close to the compositions obtainable by partial melting of gabbros, presenting a composition clearly distinct from the expected result of extreme fractional crystallization (Figure 20A). The same origin can also be inferred from the trend developed by the Khzama plagiogranites on the La vs. SiO2 diagram proposed by [106]; (see Figure 20B).
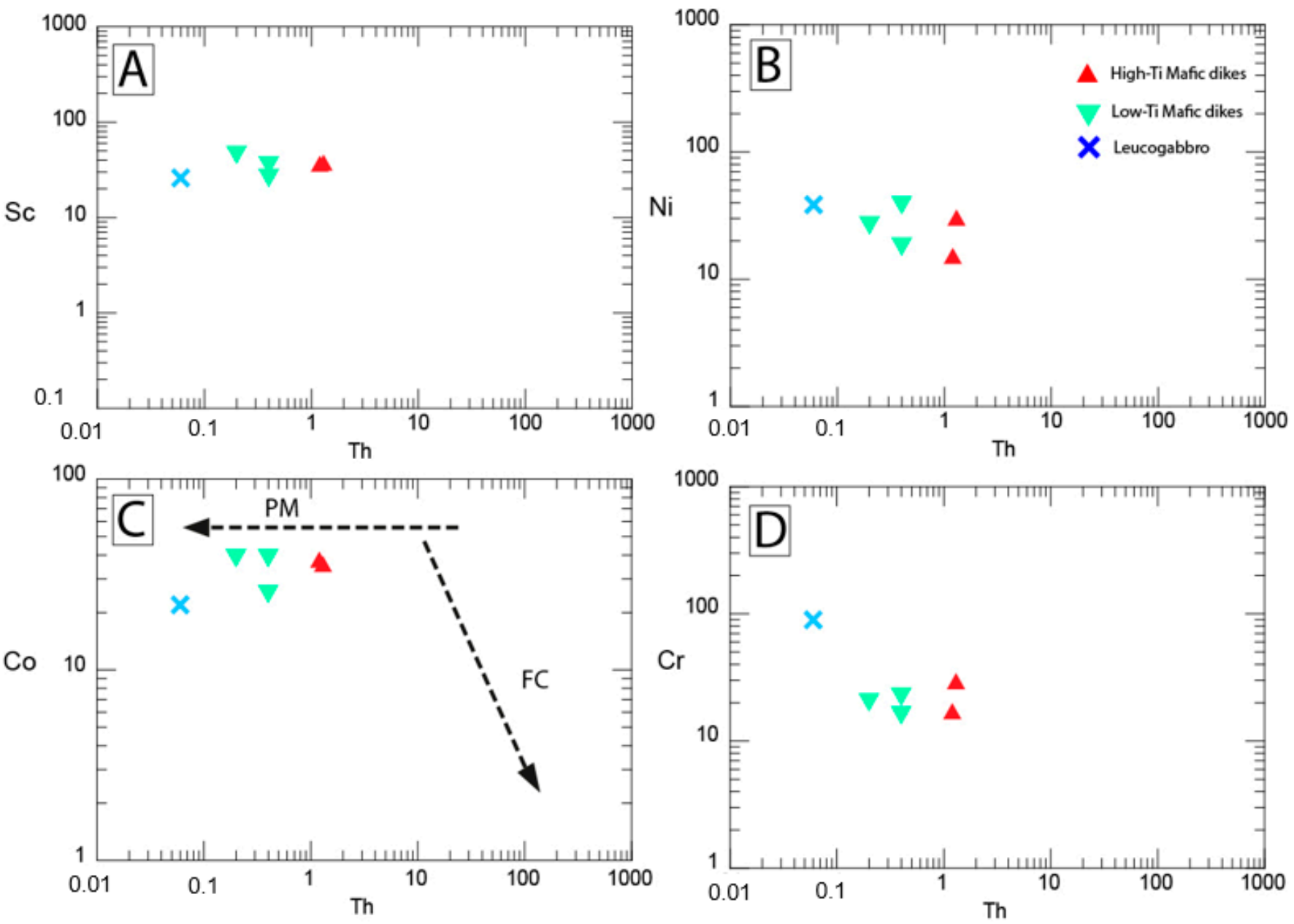

Figure 19. (A-D) Sc, Ni, Co and Cr vs. Th diagrams for the two geochemical groups of the mafic dikes of the sheeted dike complex of Khzama ophiolite (Anti-Atlas, Morocco). After [100]. See also [103]. 

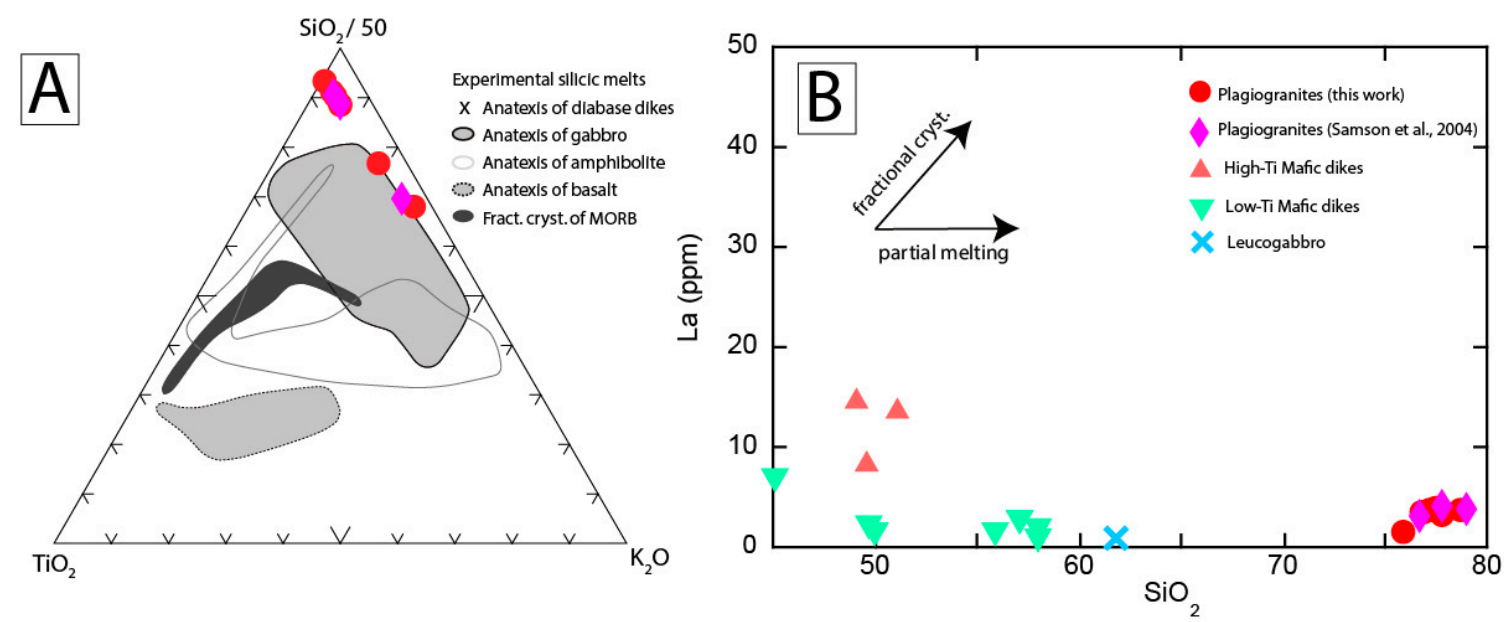

Figure 20. (A) $\mathrm{TiO}_{2}-\mathrm{SiO}_{2} / 50-\mathrm{K}_{2} \mathrm{O}$ ternary [105], based on experiments involving hydrous melting of mafic ocean crust and fractional crystallization of mid-ocean ridge basalt (MORB). Plagiogranite samples are from this study and from [22]. They lie on the field of partial melting of gabbro. The different fields displayed are from [105]; (diabase anatexis), [107]; (gabbro anatexis), [108]; (amphibolite anatexis), [109]; (basalt anatexis), and [110,111]; (fractional crystallization of MORB), adopted from [104]; (B) La versus $\mathrm{SiO}_{2}$ diagram proposed by [106]; for evaluating petrogenesis of silicic rocks in ocean crust, [104].

\subsection{Age of Khzama Ophiolites and Correlation with Bou Azzer Ophiolites}

The SHRIMP U-Pb geochronologic data of the ophiolitic leucogabbroic sample represent the first age produced using radiometric analysis of zircons extracted from the mafic rocks intruded by the sheeted dike complex at the Khzama ophiolite. This rock shows a concordia age of $763 \pm 5 \mathrm{Ma}$ (MSWD of concordance $=0.47$, probability of concordance $=0.49)$ interpreted to date the magmatic crystallization of the oceanic crust now cropping out as part of the tectonically emplaced Khzama ophiolite (Figure 15A). This age is approximately 1 to 2 Ma older than those obtained for two plagiogranites sampled in the studied area by [22], using high-precision U-Pb zircon techniques (TIMS method). For these plagiogranites [22] obtained upper intersections with concordia at 761.1 + 1.9/ $-1.6 \mathrm{Ma}$ (small pluton) and at $762+1 /-2 \mathrm{Ma}$ (folded dike), which are overlapping within error. It is worth to mention that an inherited age of $784 \pm 7 \mathrm{Ma}$ was obtained from the leucogabbroic sample of this study, suggesting an older magmatic event. Interestingly this value overlaps, within error, with the age of $777 \pm 4.7$ Ma newly obtained for one of the plagiogranites. The age of $777 \pm 4.7$ Ma proposed for the plagiogranitic sample presented in this study (sample ALTZ68) is 13 Myr older than the age obtained for the leucogabbroic sample dated at $763 \pm 5 \mathrm{Ma}$ and $15 \mathrm{Myr}$ older than the ca. $762 \mathrm{Ma}$ age of plagiogranites of [22]. Such an age difference can be explained by two hypotheses: (i) the ca. $777 \mathrm{Ma}$ plagiogranites are from a different felsic magmatic event that supposedly occurred during the early stages of the formation of the oceanic crust of the Khzama ophiolites. This would be supported by their different REE patterns with a clear positive Eu-anomaly, while a negative one is recorded for the [22] plagiogranites and also in this study, for other felsic samples, not dated. Or (ii) the 777 Ma plagiogranites and 763 Ma leucogabbro can be a part of a long-lived process of plagiogranite production including interaction with different components causing changes in their geochemical signature.

More to east of the Anti-Atlas belt in Bou Azzer inlier, a metagabbroic unit belonging to the Bougmane complex at the Assif n'Bougmane locality (most western part of the Bou Azzer inlier) was dated at $697 \pm 8 \mathrm{Ma}$ (U-Pb on zircon) by $[10,112]$ and interpreted by the authors as a dismembered element of the ophiolitic assemblage that is tectonically emplaced to the south.

The proximity of the Khzama and Bou Azzer ophiolites to the east leads to the assumption of the possibility that they may all simply be dismembered pieces of a single, larger ophiolite body [22]. This proposal is supported by the age of $759 \pm 2$ Ma proposed by [12] for the Bou Azzer ophiolite. In addition, the petrological and geochemical results 
as well as the $\mathrm{Nd}$ isotopic data $[21,22]$ confirm that they belong to the same portion of a suprasubduction oceanic lithosphere ([12], with an age of circa 763-759 Ma [12,22 and this work].

In the Khzama ophiolite, the age of $777 \pm 4.7$ Ma proposed for the plagiogranitic sample presented in this study (sample ALTZ68) is in fact 13 Ma to 15 Ma older than the age obtained for our leucogabbroic sample dated at $763 \pm 5 \mathrm{Ma}$ and the plagiogranites of [22], dated at ca. 762 Ma suggesting a long lived suprasubduction zone. Assuming that the context in the Khzama ophiolite is an ultraslow-spreading ridge (spreading velocity around $2-3 \mathrm{~cm}$ /year for an ultraslow-spreading ridge), the width of the Khzama backarc basin is calculated to be $300-450 \mathrm{Km}$ (Figure 21). It is unlikely, if not impossible, that such a large oceanic domain, similar in width to the Tethyan ophiolites (Piemont-Liguria ocean) in the Western Alps, could have the same age everywhere (see Figures 5 and 6 of [113]; see also [114]. The Neoproterozoic oceanic crust exposed in the Khzama ophiolite is extensively deformed and metamorphosed. The mylonitized and amphibolitized sheeted dikes and flaser gabbros and their contact relationships suggest possible emplacement into a transform fault and fracture zone environment. In the central part of the Khzama ophiolite complex, it was described by [30] as a metasedimentary succession of conglomerates and breccias with pebbles derived from rocks of the ophiolitic suite. These coarse clastic rock deposits occur as E-W slivers between Tourtit and Tachakoucht units and may be interpreted as products of intraoceanic faulting that can be observed in modern transform zones. In addition, many ophiolite belts that are hundreds of kilometers long, such as the Coast Range ophiolite of California (e.g., [115]) and many Tethyan ophiolites (e.g., [114]), show a restricted (generally $5 \mathrm{Ma}$ or less) age range. Such ophiolite belts are inconsistent with subduction initiation along an oceanic transform fault or fracture zone. In our case, the long lived Khzama ophiolite (duration between 15 and $17 \mathrm{Ma}$ ) is consistent with emplacement along an oceanic transform fault. In the schematic diagram of [12]; (see their Figures 1 and 16), it may be possible that the Southern Ait Ahmane ophiolites of Bou Azzer could be older than ca. 759 Ma obtained by [12]; for the Northern Ait Ahmane ophiolites of Bou Azzer and have the same age as our Khzama plagiogranite dated at $777 \pm 4.7 \mathrm{Ma}$ (777 $\pm 5 \mathrm{Ma}$ ). These ophiolites postdate the 885-883 Ma Iguerda-Taïfast Large Igneous Province that are hypothesized to mark the onset of the rifting on the northern edge of the West African craton and the disassembly of Rodinia [24,116,117]. Similar-aged LIPs also occur on other cratons such as the Tarim Terrane (North China) and the Congo Craton (Central Africa); these might reflect rifting during the late stage in the assembly of the Rodinia supercontinent ([24]; and references therein). The age of the Anti-Atlas ophiolites should also predate the oldest magmatic flare-up at 760-730 Ma in the development of the Anti-Atlas Belt oceanic arc complexes [28]. These authors showed that these arc complexes are remnants of a long-lived (120 Myr) Neoproterozoic oceanic arc, punctuated by three successive magmatic episodes (760-730 Ma, 710-690 Ma, and 660-640 Ma respectively) interspersed with periods of magmatic quiescence (Figure 22). 


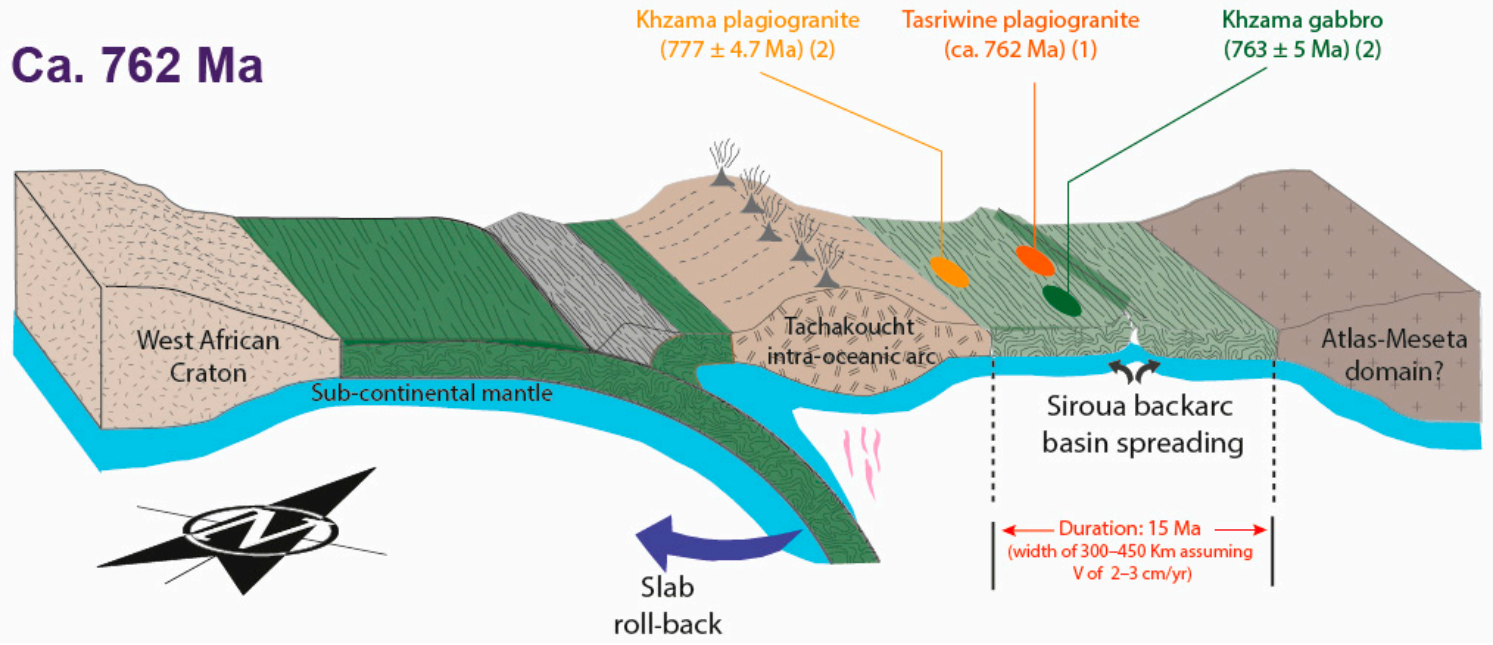

Figure 21. Conceptual 3D model showing the temporal and spatial evolution of the Khzama backarc basin. The age of the dated rocks from the Khzama ophiolite ranges between ca. 777 and $762 \mathrm{Ma}$ ([22], this study), which gives a duration of seafloor accretion of 15 m.y. during which the Khzama backarc basin could have reached in a maximum width of about $300-450 \mathrm{~km}$. For this estimate was considered a maximum spreading rate of $2-3 \mathrm{~cm} / \mathrm{yr}$, corresponding to the upper bound in modern spreading systems [113]. Abbreviation; V = Velocity.

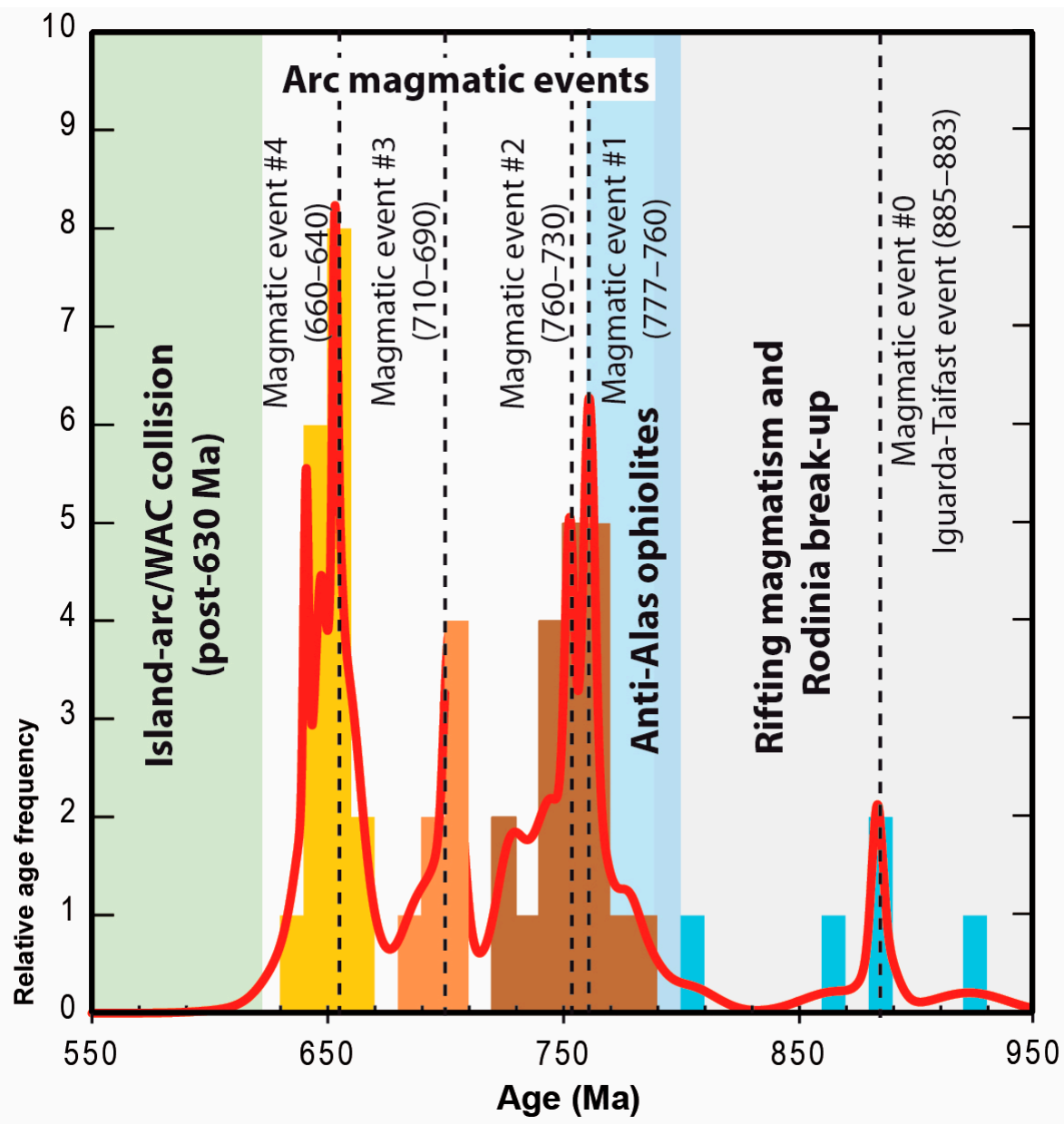

Figure 22. Frequency histogram of U-Pb ages $(n=50)$ of Moroccan Neoproterozoic magmatic events discussed in this paper (modified after [28]. Ages are from this study, [12,116,117]. The dashed black lines correspond to the median age value for each magmatic event. The solid red line describes a probability density function weighting each age determination according to its uncertainty. The probability density histogram has been calculated using Isoplot 4.15 [44]. 


\subsection{The Iriri Migmatic Complex and Pan-African Island Arc Accretion Record in the Siroua Inlier}

The age at $740 \pm 12 \mathrm{Ma}$ (Figure 15B) for the metamorphic overgrowth obtained for the plagiogranitic sample (ALTZ68) is similar to the previously obtained age of $743 \pm 14 \mathrm{Ma}$ from zircon grains of tonalitic gneiss thought to represent the protolith of the Iriri migmatite [21]. On the ophiolitic segment of the Bou Azzer inlier at the Assif n' Bougmane area, similar ages are also documented. Ref. [11] obtained a weighted mean age of $755 \pm 9$ Ma for a foliated fine- to coarse grained gneiss from the Bou Azzer area (close to the Bou Azzer mine) and a weighted mean age of $745 \pm 5 \mathrm{Ma}$ for an orthogneiss collected in the Assif n'Bougmane area. These obtained ages are considered by the authors to represent the emplacement age of the granitic protoliths of the orthogneisses later gneissified probably before $695 \pm 7 \mathrm{Ma}$, which is the age of the Oumlil's leuco-granodiorite [32]. The circa 740 Ma ages, are consistent with an age of $741 \pm 9$ Ma considered by [112]; as the best estimate age of the Oumlill granite crystallization in the Bou Azzer inlier. In addition, [118] obtained concordant U-Pb zircon ages of $753+1 /-2 \mathrm{Ma}$ for augen granite and 752.2 $\pm 2.4 \mathrm{Ma}$ for a metagabbro in the Tazigzaout area. Both ages have been considered by [118], as the best estimates of the crystallization ages of their igneous protoliths.

These ages occurred during the 760-730 Ma magmatic pulse (IGN1) attributable to the first flare up of three magmatic pulses (IGN1-2-3: 750-700-650 Ma respectively, [34]). This pulse corresponds to the magmatic events 1 to 4 in Figure 22 of our study during which the Bougmane arc complex grows in an intra-oceanic arc setting. The plagiogranitic sample (sample ALTZ68) of our study documents a younger metamorphic overgrowth with an age of $642 \pm 23 \mathrm{Ma}$ (grain number; 1.2). This date is younger but overlapping within 1 sigma error with the age at $663 \pm 13$ Ma reported by [21], as the age of metamorphism and the best direct estimate of the timing of Pan-African island arc accretion in the Siroua Window [21].

\subsection{The Record of the Late Neoproterozoic Rifting in the Siroua Inlier}

In the West African Craton (WAC) the Late Neoproterozoic marks the onset of a period of rifting leading to opening of an ocean basin on its northern edge. This rifting has been associated with the extension leading to the break-up of the supercontinent Rodinia $[23,24,117]$. In the Bou-Azzer (Ait Ahmane) and Siroua (Khzama) inliers, relic of the oceanic crust then formed (Bou-Azzer Group) is found as highly sheared allochthonous ophiolite complexes ([12], and references therein), yet crustal (mafic meta-cumulates, meta-basaltic sheeted dikes, and, to a smaller extent, pillow lavas) and mantle rocks (serpentinized peridotites with chromite pods) are recognizable [13-15]. According to their geochemical fingerprints the ophiolite was emplaced in a supra-subduction zone [12,16-20,28]. Plagiogranite intrusions (ca. $760 \mathrm{Ma}$; U-Pb zircon age; [12,22]) in the Siroua and Bou Azzer inliers indicate the minimum age of oceanic crust formation, in the absence of reliable ages for the lower Anti-Atlas Supergroup. The consumption of this ocean basin is related with island arc development (the Iriri Group in the Siroua Inlier; [21,27,33]). Two U-Pb SHRIMP ages of $743 \pm 14$ and $663 \pm 13$ Ma were obtained for cores and overgrowths of zircon grains, respectively. The older one was interpreted as the age of crystallization of the migmatite protolith in an island arc setting, whereas the younger age (from rim) is thought to represent the timing of obduction and arc accretion to the northern margin of the WAC [21]. A younger age of $647.2 \pm 1.7 \mathrm{Ma}$ (Sm-Nd in garnet) was obtained by [119], for the Tasriwine ophiolite complex in the Siroua Inlier allowing to consider that the development of the Anti-Atlas Belt oceanic arc complexes occurred in three main phases at ca. 750, 700, and 650 Ma while an early major tectonic episode occurred between 730 and $700 \mathrm{Ma}[28,34]$. However, the timing of rifting has been unclear and the U-Pb dating in this paper helps constrain the rift timing. Ages of $802 \pm 12 \mathrm{Ma}, 866 \pm 15$ and ca. $922 \mathrm{Ma}$ recorded by the sample ALTZ68 are reported for the first time in the Siroua inlier. The two older (866 \pm 15 and ca. $922 \mathrm{Ma}$ ) ages are recognized also on the Tachdamt Formation of the lower Anti-Atlas Supergroup [24] in the Bou Azzer inlier. The two ages are also consistent with the ca. $883 \mathrm{Ma}$ U-Pb SHRIMP zircon ages for two tuff horizons interbedded in the 
basal part of the Tachdamt Formation in the Siroua inlier $[117,120]$. The age of ca. $922 \mathrm{Ma}$ overlaps within 1 sigma error with $930 \pm 12 \mathrm{Ma}$, the date used by [24] to constraint the maximum deposition age of the Tachdamt Formation. These new dates support a rifting event between $930 \mathrm{Ma}$ and $802 \mathrm{Ma}$ which is consistent with the suggestion for peak rifting at $883 \mathrm{Ma}$, coinciding with the 885-883 Ma Iguerda-Taïfast LIP.

\section{Conclusions}

The main conclusions arising from this study are:

(1) The tectonomagmatic setting of the mafic and the felsic rocks associated with the sheeted dike complex and consequently the tectonomagmatic setting of Khzama ophiolite is deciphered by using the immobile elements diagrams combined with the interpretation of REE spectra. The magmatic rocks preserved at the Khzama ophiolites were generated in a supra-subduction backarc setting.

(2) The source and the depth of magma are evaluated using the $\mathrm{Ce} / \mathrm{Yb}$ ratio of basaltic rocks. The studied mafic rocks show low $\mathrm{Ce} / \mathrm{Yb}$ ratios indicative of a spinel peridotite source. Moderate variations in Th contents for the studied mafic rocks is observed, while an insignificant variation is observed for $\mathrm{Sc}, \mathrm{Ni}, \mathrm{Cr}$ and $\mathrm{Co}$ contents indicating a less significant control by fractional crystallization rather than partial melting processes.

(3) The SHRIMP U-Pb geochronologic data of the leucogabbroic sample yields a concordant age at $763 \pm 5 \mathrm{Ma}$, which is the first one produced using radio-isotopic analyses of zircon grains extracted from the mafic basement intruded by the sheeted dike complex of the Khzama ophiolite. This age is identical, within error, with the previously proposed age at ca. $761 \mathrm{Ma}$.

(4) An inherited age of $784 \pm 7$ Ma was obtained from the leucogabbroic sample.

(5) Two distinct geochemical groups can be distinguished within the sheeted dike complex of the Khzama ophiolite: a Low-Ti $(<1.2 \mathrm{wt} \%)$ and High-Ti dikes $(>2.1 \mathrm{wt} \%)$.

(6) The plagiogranite dikes of this study plot mostly on the rhyodacite-rhyolite/granite fields. Because of their modal content, mineralogy and major element chemistry, these felsic rocks are classified as high silica-low alumina trondhjemites.

(7) The age of $776.6 \pm 4.7$ Ma proposed for the plagiogranitic sample presented in this study (sample ALTZ68) is slightly older (13 $\pm 7 \mathrm{Ma})$ than the age here obtained for the leucogabbroic sample (763 $\pm 5 \mathrm{Ma}$ ) and, also, than age previously obtained by [22], for plagiogranites with somewhat distinct geochemical signatures. This point to a long-lived process of plagiogranite production.

(8) The plagiogranitic sample (sample ALTZ68) of this study recorded two metamorphic overgrowths. The first one at $740 \pm 12 \mathrm{Ma}$, which is similar to the previously obtained age of $743 \pm 14$ Ma from zircon grains of tonalitic gneiss thought to represent the protolith of the Iriri migmatite. The second one has an age of $642 \pm 23 \mathrm{Ma}$, which is younger but overlapping within 1 sigma error with the $663 \pm 13$ Ma reported by [21], as the age of metamorphism and the best direct estimate of the timing of Pan-African island arc accretion in the Siroua Window.

Supplementary Materials: The following are available online at https:/ / www.mdpi.com/2075-163 X/11/1/56/s1, Table S1. SHRIMP II zircon U-Th-Pb results of leucogabbro (sample ALTZ61) of the Khzama ophiolite. Table S2. SHRIMP II zircon U-Th-Pb results of the plagiogranite (sample ALTZ68) of the Khzama ophiolite. Table S3. Neoproterozoic U-Pb ages of the Iguerda-Taïfast Large Igneous Province (rifting), the ophiolites (suprasubduction backarc basin) and the protolithic ages of (meta-) igneous rocks of oceanic arc complexes of the Anti-Atlas.

Author Contributions: Conceptualization, L.C., H.A. and N.Y.; Data curation, L.C., A.A.L., H.A. and N.Y.; Formal analysis, C.C.G.T., M.A.S.B., K.S. and J.-L.B.; Funding acquisition, C.C.G.T.; Investigation, L.C., A.A.L., H.A. and N.Y.; Methodology, L.C., H.A. and N.Y.; Project administration, N.Y., C.C.G.T. and M.A.B.; Resources, L.M. and A.B.; Software, A.A.L. and W.E.M.; Supervision, H.A. and N.Y.; Validation, N.Y., J.M., A.M., M.A.B., K.H., L.M. and A.B.; Writing-original draft, L.C., A.A.L., H.A. and N.Y.; Writing—review \& editing, W.E.M., C.C.G.T., J.M., A.M., A.G., M.A.B., M.K.B., A.S., K.H., L.M. and A.B. All authors have read and agreed to the published version of the manuscript. 
Funding: This work was funded by the Universidade de São Paulo: USP-UCAM/2016, the Russian Science Foundation: 14.Y26.31.0012 and by the FCT-Fundação para a Ciência e a Tecnologia: UIDB/50019/2020.

Institutional Review Board Statement: Not applicable.

Informed Consent Statement: Not applicable.

Data Availability Statement: Not applicable.

Acknowledgments: Most of this work was carried out at the Department of Geology of the Faculty of Sciences-Semlalia, Cadi Ayyad University of Marrakech and the "Centro de Pesquisas Geocronológicas (CPGeo), Instituto de Geociências (IG), Universidade de São Paulo-USP, São Paulo (SP), Brazil" within the framework of the scientific and technical agreement between the São Paulo University and the Cadi Ayyad University (responsibles Colombo Celso Gaeta Tassinari and Nasrrddine Youbi). João Mata acknowledges the financial FCT support through project UIDB/50019/2020 - IDL. Nasrrddine Youbi is supported by Russian Mega-Grant 14.Y26.31.0012. Thoughtful comments by three anonymous reviewers on this manuscript are gratefully acknowledged. We greatly appreciate thoughtful suggestions of Richard Ernst that helped to improve the manuscript.

Conflicts of Interest: The authors declare no conflict of interest.

\section{References}

1. Metcalf, R.V.; Shervais, J.W. Suprasubduction-Zone Ophiolites: Is There Really an Ophiolite Conundrum? Special Paper 438: Ophiolites, Arcs, and Batholiths: A Tribute to Cliff Hopson; Geological Society of America: McLean, VA, USA, 2008; pp. 191-222. [CrossRef]

2. Dilek, Y.; Furnes, H. Ophiolite genesis and global tectonics: Geochemical and tectonic fingerprinting of ancient oceanic lithosphere. Geol. Soc. Am. Bull. 2011, 123, 387-411. [CrossRef]

3. Dilek, Y.; Furnes, H. Ophiolites and Their Origins. Elements 2014, 10, 93-100. [CrossRef]

4. Stern, R.J.; Bloomer, S.H. Subduction zone infancy: Examples from the Eocene Izu-Bonin-Mariana and Jurassic California arcs. Geol. Soc. Am. Bull. 1992, 104, 1621-1636. [CrossRef]

5. Ohara, Y.; Stern, R.J.; Ishii, T.; Yurimoto, H.; Yamazaki, T. Peridotites from the Mariana Trough: First look at the mantle beneath an active back-arc basin. Contr. Mineral. Petrol. 2002, 143, 1-18. [CrossRef]

6. Pearce, J.A. Supra-Subduction Zone Ophiolites: The Search for Modern Analogues. Special Paper 373: Ophiolite Concept and the Evolution of Geological Thought; Geological Society of America: McLean, VA, USA, 2003; pp. 269-293. [CrossRef]

7. Stern, R.J.; Reagan, M.; Ishizuka, O.; Ohara, Y.; Whattam, S. To understand subduction initiation, study forearc crust: To understand forearc crust, study ophiolites. Lithosphere 2012, 4, 469-483. [CrossRef]

8. Monsef, I.; Monsef, R.; Mata, J.; Zhang, Z.; Pirouz, M.; Rezaeian, M.; Esmaeili, R.; Xiao, W. Evidence for an early-MORB to fore-arc evolution within the Zagros suture zone: Constraints from zircon $\mathrm{U}-\mathrm{Pb}$ geochronology and geochemistry of the Neyriz ophiolite (South Iran). Gondwana Res. 2018, 62, 287-305. [CrossRef]

9. Thomas, R.J.; Fekkak, A.; Ennih, N.; Errami, E.; Loughlin, S.C.; Gresse, P.G.; Chevallier, L.P.; Liégeois, J.-P. A new lithostratigraphic framework for the Anti-Atlas Orogen, Morocco. J. Afr. Earth Sci. 2004, 39, 217-226. [CrossRef]

10. El Hadi, H.; Simancas, J.F.; Martináz-Poyatos, D.; Azor, A.; Tahiri, A.; Montero, P.; Fanning, C.M.; Bea, F.; González-Lodeiro, F. Structural and geochronological constraints on the evolution of the Bou Azzer Neoproterozoic ophiolite (Anti-Atlas, Morocco). Precambrian Res. 2010, 182, 1-14. [CrossRef]

11. Blein, O.; Baudin, T.; Chèvremont, P.; Soulaimani, A.; Admou, H.; Gasquet, P.; Cocherie, A.; Egal, E.; Youbi, N.; Razin, P.; et al. Geochronological constraints on the polycyclic magmatism in the Bou Azzer-El Graara inlier (Central Anti-Atlas Morocco). J. Afr. Earth Sci. 2014, 99, 287-306. [CrossRef]

12. Hodel, F.; Triantafyllou, A.; Berger, J.; Macouin, M.; Baele, J.-M.; Mattielli, N.; Monnier, C.; Trindade, R.I.F.; Ducea, M.N.; Chatir, A.; et al. The Moroccan Anti-Atlas ophiolites: Timing and melting processes in an intra-oceanic arc-back-arc environment. Gondwana Res. 2020. [CrossRef]

13. Leblanc, M. Ophiolites Précambriennes et Gris Arsenies de Cobalt (Bou Azzer, Morocco). Ph.D. Thesis, Université de Paris VI, Paris, France, 1975; p. 329.

14. Leblanc, M. The Late Proterozoic Ophiolites of Bou Azzer (Morocco): Evidence for Pan-African Plate Tectonics. Dev. Precambrian Geol. 1981, 435-451. [CrossRef]

15. Admou, H.; Juteau, T. Découverte d'un système hydrothermal océanique fossile dans l'ophiolite antécambrienne de Khzama (massif du Siroua, Anti-Atlas marocain). Comptes Rendus l'Académie Sci. Ser. IIA Earth Planet. Sci. 1998, 327, 335-340. [CrossRef]

16. Bodinier, J.L.; Dupuy, C.; Dostal, J. Geochemistry of Precambrian ophiolites from Bou Azzer, Morocco. Contr. Mineral. Petrol. 1984, 87, 43-50. [CrossRef]

17. Naidoo, D.D.; Bloomer, S.H.; Saquaque, A.; Hefferan, K. Geochemistry and significance of metavolcanic rocks from the Bou Azzer-El Graara ophiolite (Morocco). Precambrian Res. 1991, 62, 369-371. [CrossRef] 
18. Ahmed, A.; Arai, S.; Abdelaziz, Y.; Rahimi, A. Spinel composition as a petrogenetic indicator of the mantle section in the Neoproterozoic Bou Azzer ophiolite, Anti-Atlas, Morocco. Precambrian Res. 2005, 138, 225-234. [CrossRef]

19. Hodel, F.; Macouin, M.; Triantafyllou, A.; Carlut, J.; Berger, J.; Rousse, S.; Ennih, N.; Trindade, R.I.F. Unusual massive magnetite veins and highly altered Cr-spinels as relics of a Cl-rich acidic hydrothermal event in Neoproterozoic serpentinites (Bou Azzer ophiolite, Anti-Atlas, Morocco). Precambrian Res. 2017, 300, 151-167. [CrossRef]

20. Triantafyllou, A.; Hodel, F.; Berger, J.; Macouin, M.; Baele, J.M.; Mattielli, N.; Monnier, C.; Ducea, M.N.; Poujol, M.; Langlade, J.; et al. The Bou Azzer and Sirwa Ophiolites (Anti-Atlas, Morocco): Insight into Polyphased Subduction-Accretion Dynamics during Neoproterozoic Times; GSA Annual Meeting: Phoenix, AZ, USA, 2019. [CrossRef]

21. Thomas, R.J.; Chevallier, L.P.; Gresse, P.G.; Harmer, R.E.; Eglington, B.M.; Armstrong, R.A.; de Beer, C.H.; Martini, J.E.J.; de Kock, G.S.; Macey, P.H.; et al. Precambrian evolution of the Sirwa Window, Anti-Atlas Orogen, Morocco. Precambrian Res. 2002, 118 , 1-57. [CrossRef]

22. Samson, S.D.; Inglis, J.D.; D’Lemos, R.S.; Admou, H.; Blichert-Toft, J.; Hefferan, K. Geochronological, geochemical, and Nd-Hf isotopic constraints on the origin of Neoproterozoic plagiogranites in the Tasriwine ophiolite, Anti-Atlas orogen, Morocco. Precambrian Res. 2004, 135, 133-147. [CrossRef]

23. Gasquet, D.; Ennih, N.; Liégeois, J.-P.; Soulaimani, A.; Michard, A. The Pan-African Belt. Lect. Notes Earth Sci. 2008, 33-64. [CrossRef]

24. Ait Lahna, A.; Youbi, N.; Gaeta Tassinari, C.C.; Stipp Basei, M.A.; Ernst, R.E.; Chaib, L.; Barzouk, A.; Mata, J.; Gärtner, A.; Admou, H.; et al. Revised stratigraphic framework for the lower Anti-Atlas supergroup based on U-Pb geochronology of magmatic and detrital zircons (Zenaga and Bou Azzer-El Graara inliers, Anti-Atlas Belt, Morocco). J. Afr. Earth Sci. 2020, 103946. [CrossRef]

25. Admou, H. Structuration de la Paleosuture Ophiolitique Panafricaine de Bou Azzer-Sirou (Anti-Atlas central, Maroc). Ph.D. Thesis, Université Cadi Ayyad, Marrakesh, Morocco, 2000; 201p.

26. Ennih, N.; Liégeois, J.P. The Moroccan Anti-Atlas: The West African craton passive margin with limited Pan-African activity. Implications for the northern limit of the craton. Precambrian Res. 2001, 112, 289-302. [CrossRef]

27. Triantafyllou, A.; Berger, J.; Baele, J.-M.; Diot, H.; Ennih, N.; Plissart, G.; Monnier, C.; Watlet, A.; Bruguier, O.; Spagna, P.; et al. The Tachakoucht-Iriri-Tourtit arc complex (Moroccan Anti-Atlas): Neoproterozoic records of polyphased subduction-accretion dynamics during the Pan-African orogeny. J. Geodyn. 2016, 96, 81-103. [CrossRef]

28. Triantafyllou, A.; Berger, J.; Baele, J.-M.; Mattielli, N.; Ducea, M.N.; Sterckx, S.; Samson, S.; Hodel, F.; Ennih, N. Episodic magmatism during the growth of a Neoproterozoic oceanic arc (Anti-Atlas, Morocco). Precambrian Res. 2020, 105610. [CrossRef]

29. Chabane, A. Les Roches Vertes du Proterozoique Supérieur de Khzama (Siroua, Anti-Atlas Central, Maroc), un Exemple Précambrien D'ophiolite d'avant arc formée en Contexte Transformante. Ph.D. Thesis, University Cadi Ayyad, Marrakech, Morocco, 1991; 452p.

30. El Boukhari, A.; Chabane, A.; Rocci, G.; Tane, J.-L. Upper proterozoic ophiolites of the Siroua Massif (anti-atlas, Morocco) a marginal sea and transform fault system. J. Afr. Earth Sci. (Middle East) 1992, 14, 67-80. [CrossRef]

31. Saquaque. Un Exemple de Suture-Arc: Le Précambrien de l'Anti-Atlas Centre Oriental (Maroc). Ph.D. Thesis, Université Cadi Ayyad, Marrakech, Morocco, 1992; 342p.

32. Admou, H.; Fekkak, A.; Razin, P.H.; Egal, E.; Youbi, N.; Soulaimani, A.; Blein, O.; Baudin, T.; Chevremont, P.H. Carte géologique au 1/50 000), feuille Aït Ahmane. Notes Mém. Serv. Géol. Maroc 2013, 533, 154.

33. Triantafyllou, A. Evolution Géodynamique d'un arc Insulaire Néoprotérozoïque de l'Anti-Atlas Marocain: Caractérisation des Processus de Croissance Intra-Océanique et d'accrétion. Ph.D. Thesis, Université de Nantes, Nantes, France, 2015.

34. Triantafyllou, A.; Berger, J.; Baele, J.M.; Bruguier, O.; Diot, H.; Ennih, N.; Monnier, C.; Plissart, G.; Vandycke, S.; Watlet, A. Intra-oceanic arc growth driven by magmatic and tectonic processes recorded in the Neoproterozoic Bougmane Arc complex (Anti-Atlas, Morocco). Precambrian Res. 2018, 304, 39-63. [CrossRef]

35. Dilek, Y.; Thy, P.; Moores, E.M.; Ramsden, T.W. Tectonic evolution of the Troodos ophiolite within the Tethyan framework. Tectonics 1990, 9, 811-823. [CrossRef]

36. Dilek, Y.; Kempton, P.D.; Thy, P.; Hurst, S.D. Structure and petrology of hydrothermal veins in gabbroic rocks from sites 921 to 924, MARK area (LEG 153): Alteration history of slow-spread lower oceanic. In Proceedings of the Ocean Drilling Program, Scientific Results; Karson, J.A., Cannat, M., Miller, D.J., Elthon, D., Eds.; Ocean Drilling Program: College Station, TX, USA, 1997; Volume 153.

37. Furnes, H.; Robins, B.; De Wit, M.J. Geochemistry and Petrology of lavas in the upper onverwacht suite, Barberton Mountain Land, South Africa. S. Afr. J. Geol. 2012, 115, 171-210. [CrossRef]

38. Admou, H.; Soulaimani, A. Nouveaux guides géologiques et miniers du Maroc. Circuit 16, massif de Siroua. Notes et Mémoires du Serv. Géol. Maroc 2011, 563, 83-104.

39. Cotten, J.; Le Dez, A.; Bau, M.; Caroff, M.; Maury, R.C.; Dulski, P.; Fourcade, S.; Bohn, M.; Brousse, R. Origin of anomalous rare earth element and yttrium enrichments in subaerially exposed basalts: Evidence from French Polynesia. Chem. Geol. 1995, 119, 115-138. [CrossRef]

40. Williams, I.S. U-Th-Pb geochronology by ion microprobe. In Applications of Microanalytical Techniques to Understanding Mineralizing Processes. Reviews in Economic Geology; McKibben, M.A., Shanks, W.C., III, Ridley, W.I., Eds.; Society of Economic Geologists: Littleton, CO, USA, 1998; Volume 7, pp. 1-35. 
41. Sato, K.; Tassinari, C.C.G.; Basei, M.A.S.; Siga Júnior, O.; Onoe, A.T.; Souza, M.D. Sensitive High Resolution Ion Microprobe (SHRIMP IIe/MC) of the Institute of Geosciences of the University of São Paulo, Brazil: Analytical method and first results. Geologia USP. Série Científica 2014, 14, 3-18. [CrossRef]

42. Black, L.P.; Kamoc, L.S.; Allen, C.M.; Davis, D.W.; Aleinikoff, J.N.; Valley, J.N.; Mundil, R.; Campbell, I.H.; Korsch, R.J.; Williams, I.S.; et al. Improved 206Pb/238U microprobe geochronology by the monitoring of a trace-element-related matrix effect; SHRIMP, ID-TIMS, ELA-ICP-MS and oxygen isotope documentation for a series of zircon standards. Chem. Geol. 2004, 205, 115-140. [CrossRef]

43. Spencer, C.J.; Kirkland, C.L.; Taylor, R.J.M. Strategies towards statistically robust interpretations of in situ U-Pb zircon geochronology. Geosci. Front. 2016, 7, 581-589. [CrossRef]

44. Ludwig, K.R. ISOPLOT Rev.4.15: A Geochronological Toolkit for Microsoft Excel; Berkeley Geochronology Center: Berkeley, CA, USA, 2007; Volume 4, 74p.

45. Wafik, A.; Admou, H.; Saquaque, A.; El Boukhari, A.; Juteau, T. Les minéralisations sulfurées à Cu-Fe et les altérations associées dans les ophiolites protérozoïques de Bou Azzer et de Khzama (Anti-Atlas, Maroc). Ofioliti 2001, 26, 47-62.

46. Alt, C. Subseafloor processes in mid-ocean ridge hydrothermal system. In: J. Lupton, L. Mullineaux et R. Zierenberg (edit.). Ridge theoretical Institute: Phesical, chemical and biological interactions within submarine hydrothermal systems. Geophys. Monogr. Am. Geophys. 1995. [CrossRef]

47. Nehlig, P.; Haymon, R. Microthermometric study of fluid inclusions in a fossil ridge crest, hydrothermal discharge zone in the Bayda area (North Oman Ophiolite). Eos Trans. Am. Geophys. Union 1987, 68, 15-45.

48. Nehlig, P. Etude d'un Système Hydrothermal Océanique Fossile: L'ophiolite de Sémail (Oman). Ph.D. Thesis, Université de Bretagne Occidentale, Brest, France, 1989; 321p.

49. Nicolas, A.; Ildefonse, B.; Boudier, F.; Lenoir, X.; Ben Ismail, W. Dike distribution in the Oman-United Arab Emirates ophiolite. Mar. Geophys. Res. 2000, 21, 269-287. [CrossRef]

50. Nicolas, A.; Boudier, F.; Koepke, J.; France, L.; Ildefonse, B.; Mevel, C. Root zone of the sheeted dike complex in the Oman ophiolite. Geochem. Geophys. Geosyst. 2008, 9, Q05001. [CrossRef]

51. Barker, F. Trondhjemite: Definition, Environment and Hypotheses of Origin. Trondhjemites Dacites Relat. Rocks 1979, 1-12. [CrossRef]

52. Pearce, J.A. A users guide to basalt discrimination diagrams. In: Wyman, D.A. (Eds.) Trace Element Geochemistry of Volcanic Rocks: Applications for Massive Sulphide Exploration. Geol. Assoc. Can. Short Course Notes 1996, 12, 79-113.

53. Winchester, J.A.; Floyd, P.A. Geochemical discrimination of different magma series and their differentiation products using immobile elements. Chem. Geol. 1977, 20, 325-343. [CrossRef]

54. Albarède, F. How deep do common basaltic magmas form and differentiate? J. Geophys. Res. 1992, 97, 10997. [CrossRef]

55. Verati, C.; Bertrand, H.; Feraud, G. The farthest record of the Central Atlantic Magmatic Province into West Africa craton: Precise Ar/Ar dating and geochemistry of Taoudenni basin intrusives (northern Mali). Earth Planet. Sci. Lett. 2005, 235, 391-407. [CrossRef]

56. Peate, D.W. The Paranà-Etendeka Province. Large Igneous Provinces: Continental, Oceanic, and Planetary Flood Volcanism; Geophysical Monograph Series 100; John, J., Mahoney Millard, F., Eds.; The American Geophysical Union: Washington, DC, USA, 1997. [CrossRef]

57. Sun, S.S.; McDonough, W.F. Chemical and isotopic systematics of oceanic basalts: Implications for mantle composition and processes. Geol. Soc. Lond. Special Publ. 1989, 42, 313-345. [CrossRef]

58. Gale, A.; Dalton, C.A.; Langmuir, C.H.; Su, Y.; Schilling, J.-G. The mean composition of ocean ridge basalts. Geochem. Geophys. Geosystems. 2013, 14, 489-518. [CrossRef]

59. Coleman, R.G.; Peterman, Z.E. Oceanic plagiogranite. J. Geophys. Res. 1975, 80, 1099-1108. [CrossRef]

60. Coleman, R.G.; Donato, M.M. Oceanic Plagiogranite Revisited. Trondhjemites Dacites Relat. Rocks 1979, 149-168. [CrossRef]

61. Aldiss, D.T. Plagiogranites from the ocean crust and ophiolites. Nature 1981, 289, 577-578. [CrossRef]

62. Pedersen, R.B.; Malpas, J. The origin of oceanic plagiogranites from the karmoy ophiolite, western Norway. Contr. Mineral. Petrol. 1984, 88, 36-52. [CrossRef]

63. Shand, S.J. Eruptive Rocks: Their Genesis, Composition, Classification and their Relations to Ore Deposits, 2nd ed.; Wiley: New York, NY, USA, 1943; 444p.

64. Hoskin PW, O.; Schaltegger, U. The Composition of Zircon and Igneous and Metamorphic Petrogenesis. Rev. Mineral. Geochem. 2003, 53, 27-62. [CrossRef]

65. Linnemann, U.; Gerdes, A.; Drost, K.; Buschmann, B. The Continuum between Cadomian Orogenesis and Opening of the Rheic Ocean: Constraints from LA-ICP-MS U-Pb Zircon Dating and Analysis of Plate-Tectonic Setting (Saxo-Thuringian Zone, Northeastern Bohemian Massif, Germany). Special Paper 423: The Evolution of the Rheic Ocean: From Avalonian-Cadomian Active Margin to Alleghenian-Variscan Collision; Geological Society of America: McLean, VA, USA, 2007; pp. 61-96. [CrossRef]

66. Cann, J.R. Rb, Sr, Y, Zr and Nb in some ocean floor basaltic rocks. Earth Planetary Sci. Lett. 1970, 10, 7-11. [CrossRef]

67. Pearce, J.A.; Cann, J.R. Ophiolite origin investigated by discriminant analysis using Ti, Zr and Y. Earth Planetary Sci. Lett. 1971, 12, 339-349. [CrossRef]

68. Pearce, J.A. Basalt geochemistry used to investigate past tectonic environments on Cyprus. Tectonophysics 1975, $25,41-67$. [CrossRef] 
69. Shervais, J.W. Birth, death, and resurrection: The life cycle of suprasubduction zone ophiolites. Geochem. Geophys. Geosyst. 2001, 2. [CrossRef]

70. Shervais, J.W. Ti-V plots and the petrogenesis of modern and ophiolitic lavas. Earth Planetary Sci. Lett. 1982, 59, 101-118. [CrossRef]

71. Saccani, E.; Bortolotti, V.; Marroni, M.; Pandolfi, L.; Photiades, A.; Principi, G. The Jurassic association of backarc basin ophiolites and calcalkaline volcanics in the Guevgueli Complex (Northern Greece): Implication for the evolution of the Vardar Zone. Ofioliti 2008, 33, 209-227.

72. Saccani, E.; Principi, G.; Garfagnoli, F.; Menna, F.B. Corsican ophiolites: Geochemistry and petrogenesis of basaltic and metabasaltic rocks. Ofioliti 2008, 33, 187-208.

73. Saccani, E.; Photiades, A.; Beccaluva, L. Petrogenesis and tectonic significance of Jurassic IAT magma types in the Hellenide ophiolites as deduced from the Rhodiani ophiolites (Pelagonian zone, Greece). Lithos 2008, 104, 71-84. [CrossRef]

74. Saccani, E.; Delavari, M.; Beccaluva, L.; Amini, S. Petrological and geochemical constraints on the origin of the Nehbandan ophiolitic complex (eastern Iran): Implication for the evolution of the Sistan Ocean. Lithos 2010, 117, 209-228. [CrossRef]

75. Saccani, E.; Allahyari, K.; Rahimzadeh, B. Petrology and geochemistry of mafic magmatic rocks from the Sarve-Abad ophiolites (Kurdistan region, Iran): Evidence for interaction between MORB-type asthenosphere and OIB-type components in the southern Neo-Tethys Ocean. Tectonophysics 2014, 621, 132-147. [CrossRef]

76. Moslempour, M.E.; Khalatbari-Jafari, M.; Ghaderi, M.; Yousefi, H.; Shahdadi, S. Petrology, geochemistry and tectonics of the extrusive sequence of Fannuj-Maskutan ophiolite, Southeastern Iran. J. Geol. Soc. Ind. 2015, 85, 604-618. [CrossRef]

77. Rudnick, R.L.; Gao, S. The Composition of the Continental Crust. In The Crust, Treatise on Geochemistry; Holland, H.D., Turekian, K.K., Eds.; Elsevier-Pergamon: Oxford, UK, 2003; Volume 3, pp. 1-64.

78. Pearce, J.A. Geochemical fingerprinting of oceanic basalts with applications to ophiolite classification and the search for Archean oceanic crust. Lithos 2008, 100, 14-48. [CrossRef]

79. Pearce, J.A. Immobile Element Fingerprinting of Ophiolites. Elements 2014, 10, 101-108. [CrossRef]

80. Pearce, J.A. Trace element characteristics of lavas from destructive plate boundaries. In Orogenic Andesites; Thorpe, R.S., Ed.; Wiley: Chichester, UK, 1982; pp. 528-548.

81. Dilek, Y.; Flower, M.F.J. Arc-trench rollback and forearc accretion: 2. A model template for ophiolites in Albania, Cyprus, and Oman. Geol. Soc. Lond. Spec. Publ. 2003, 218, 43-68. [CrossRef]

82. Beccaluva, L.; Coltorti, M.; Giunta, G.; Siena, F. Tethyan vs. Cordilleran ophiolites: A reappraisal of distinctive tectono-magmatic features of supra-subduction complexes in relation to the subduction mode. Tectonophysics 2004, 393, 163-174. [CrossRef]

83. Beccaluva, L.; Coltorti, M.; Saccani, E.; Siena, F. Magma generation and crustal accretion as evidenced by supra-subduction ophiolites of the Albanide-Hellenide Subpelagonian zone. Island Arc 2005, 14, 551-563. [CrossRef]

84. Dilek, Y.; Polat, A. Suprasubduction zone ophiolites and Archean tectonics. Geology 2008, 36, 431. [CrossRef]

85. Ishizuka, O.; Taylor, R.N.; Milton, J.A.; Nesbitt, R.W.; Yuasa, M.; Sakamoto, I. Variation in the mantle sources of the northern Izu arc with time and space-Constraints from high-precision Pb isotopes. J. Volcanol. Geotherm. Res. 2006, 156, 266-290. [CrossRef]

86. Ishizuka, O.; Tani, K.; Reagan, M.K. Izu-Bonin-Mariana Forearc Crust as a Modern Ophiolite Analogue. Elements 2014, 10, 115-120. [CrossRef]

87. Baier, J.; Audétat, A.; Keppler, H. The origin of the negative niobium tantalum anomaly in subduction zone magmas. Earth Planetary Sci. Lett. 2008, 267, 290-300. [CrossRef]

88. Saunders, A.; Tarney, J. Back-arc basins. Ocean. Basalts 1991, 219-263. [CrossRef]

89. Pearce, J.A.; Lippard, S.J.; Roberts, S. Characteristics and tectonic significance of supra-subduction zone ophiolites. Geol. Soc. Lond. Spec. Publ. 1984, 16, 77-94. [CrossRef]

90. Ishizuka, H.; Kawanobe, Y.; Sakai, H. Petrology and geochemistry of volcanic rocks dredged from the Okinawa Trough, an active back-arc basin. Geochem. J. 1990, 24, 75-92. [CrossRef]

91. Coish, R.A.; Sinton, C.W. Geochemistry of mafic dikes in the Adirondack mountains: Implications for late Proterozoic continental rifting. Contr. Mineral. Petrol. 1992, 10, 500-514. [CrossRef]

92. Spera, F.J.; Bohrson, W.A. Energy-constrained open system magmatic processes I: General model and energy-constrained assimilation and fractional crystallization (EC-AFC) formulation. J. Petrol. 2001, 42, 999-1018. [CrossRef]

93. Tian, L.; Castillo, P.R.; Hawkins, J.W.; Hilton, D.R.; Hanan, B.B.; Pietruszka, A.J. Major and trace element and Sr-Nd isotope signatures of lavas from the Central Lau Basin: Implications for the nature and influence of subduction components in the back-arc mantle. J. Volcanol. Geother. Res. 2008, 178, 657-670. [CrossRef]

94. Juteau, T.; Maury, R. La croute oceanique: Pétrologie et dynaamique endogene. Vuibert 2012, 32, 582.

95. Juteau, T.H.; Et Maury, R. Géologie de la Croûte Océanique_Pétrologie et Dynamique Endogènes; Edition Elsevier Masson: Amsterdam, The Netherlands, 1997; 367p, ISBN 2-225-85570-6.

96. McKenzie, D.; O'nions, R.K. Partial Melt Distributions from Inversion of Rare Earth Element Concentrations. J. Petrol. 1991, 32, 1021-1091. [CrossRef]

97. Johnson, K.T.M. Experimental cpx/ and garnet/melt partitioning of REE and other trace elements at high pressures: Petrogenetic implications. Mineral. Mag. 1994, 58A, 454-455. [CrossRef]

98. Gaetani, G.A.; Kent, A.J.R.; Grove, T.L.; Hutcheon, I.D.; Stolper, E.M. Mineral/melt partitioning of trace elements during hydrous peridotite partial melting. Contr. Mineral. Petrol. 2003, 145, 391-405. [CrossRef] 
99. Ellam, R.M. Lithospheric thickness as a control on basalt geochemistry. Geology 1992, 20, 153. [CrossRef]

100. Joron, J.L.; Treuil, M. Utilisation des propriétés des éléments fortement hygromagmaphiles pour l'étude de la composition chimique et de l'hétérogénéité du manteau. Bull. Soc. Geol. France 1977, S7-XIX, 1197-1205. [CrossRef]

101. Joron, J.-L.; Treuil, M. Hygromagmaphile element distributions in oceanic basalts as fingerprints of partial melting and mantle heterogeneities: A specific approach and proposal of an identification and modelling method. Geol. Soc. Lond. Spec. Publ. 1989, 42, 277-299. [CrossRef]

102. Cabanis, B.; Et Thieblemont, D. La discrimination des tholeiites continentales et des basaltes arriere-arc; proposition d'un nouveau diagramme, le triangle Th-3xTb-2xTa. Bull. Soc. Geol. France 1988, IV, 927-935. [CrossRef]

103. Hagemann, R.; Et Treuil, M. Introduction à la Géochimie Et Ses Applications; CEA: Paris, France, 1998.

104. Grimes, C.B.; Ushikubo, T.; Kozdon, R.; Valley, J.W. Perspectives on the origin of plagiogranite in ophiolites from oxygen isotopes in zircon. Lithos 2013, 179, 48-66. [CrossRef]

105. France, L.; Koepke, J.; Ildefonse, B.; Cichy, S.B.; Deschamps, F. Hydrous partial melting in the sheeted dike complex at fast spreading ridges: Experimental and natural observations. Contr. Mineral. Petrol. 2010, 160, 683-704. [CrossRef]

106. Brophy, J.G. $\mathrm{La}-\mathrm{SiO}_{2}$ and $\mathrm{Yb}-\mathrm{SiO}_{2}$ systematics in mid-ocean ridge magmas: Implications for the origin of oceanic plagiogranite. Contr. Mineral. Petrol. 2009, 158, 99-111. [CrossRef]

107. Koepke, J.; Feig, S.T.; Snow, J.; Freise, M. Petrogenesis of oceanic plagiogranites by partial melting of gabbros: An experimental study. Contr. Mineral. Petrol. 2004, 146, 414-432. [CrossRef]

108. Beard, J.S.; Lofgren, G.E. Dehydration Melting and Water-Saturated Melting of Basaltic and Andesitic Greenstones and Amphibolites at 1, 3, and 6. 9 kb. J. Petrol. 1991, 32, 365-401. [CrossRef]

109. Thy, P.; Lesher, C.E.; Mayfield, J.D. Low-pressure melting studies of basalt and basaltic andesite from the southeast Greenland continental margin and the origin of dacites at site 917. In Proceedings of the ODP, Science Research; Larsen, H.C., Duncan, R.A., Allan, J.F., Brooks, K., Eds.; Ocean Drilling Program: College Station, TX, USA, 1999; Volume 163, pp. 95-112.

110. Dixon-Spulber, S.; Rutherford, M.J. The Origin of Rhyolite and Plagiogranite in Oceanic Crust: An Experimental Study. J. Petrol. 1983, 24, 1-25. [CrossRef]

111. Berndt, J.; Koepke, J.; Holtz, F. An experimental investigation of the influence of water and oxygen fugacity on differentiation of MORB at $200 \mathrm{mPa}$. J. Petrol. 2005, 46, 135-167. [CrossRef]

112. El Hadi, H.; Tahiri, A.; Simancas, J.F.; González-Lodeiro, F.; Azor, A.; Martínez-Poyatos, D. Geoheritage in Morocco: The Neoproterozoic Ophiolite of Bou Azzer (Central Anti-Atlas). Geoheritage 2011, 3, 89-96. [CrossRef]

113. Li, X.H.; Faure, M.; Lin, W.; Manatschal, G. New isotopic constraints on age and magma genesis of an embryonic oceanic crust: The Chenaillet Ophiolite in the Western Alps. Lithos 2013, 160-161, 283-291. [CrossRef]

114. Dilek, Y.; Furnes, H. Tethyan ophiolites and Tethyan seaways. J. Geol. Soc. 2019, 176, 899-912. [CrossRef]

115. Wakabayashi, J.; Dilek, Y. What constitutes "emplacement" of an ophiolite?: Mechanisms and relationship to subduction initiation and formation of metamorphic soles. Geol. Soc. Lond. Spec. Publ. 2003, 218, 427-447. [CrossRef]

116. Kouyaté, D.; Soderlund, U.; Youbi, N.; Ernst, R.; Hafid, A.; Ikenne, M.; Soulaimani, A.; Bertrand, H.; El Janati, M.; Chaham, K.R. $\mathrm{U}-\mathrm{Pb}$ baddeleyite and zircon ages of $2040 \mathrm{Ma}, 1650 \mathrm{Ma}, 885 \mathrm{Ma}$ on dolerites in the West African craton (Anti-Atlas inliers): Possible links to breakup of Precambrian supercontinents. Lithos 2013, 174, 71-84. [CrossRef]

117. Bouougri, E.H.; Lahna, A.A.; Tassinari, C.C.G.; Basei, M.A.S.; Youbi, N.; Admou, H.; Saquaque, A.; Ahmed Boumehdi, A.; Maacha, L. Time constraints on Early Tonian Rifting and Cryogenian Arc terrane-continent convergence along the northern margin of the West African craton: Insights from SHRIMP and LA-ICP-MS zircon geochronology in the Pan-African Anti-Atlas belt (Morocco). Gondwana Res. 2020. [CrossRef]

118. D'Lemos, R.S.; Inglis, J.D.; Samson, S.D. A newly discovered orogenic event in Morocco: Neoproterozic ages for supposed Eburnean basement of the Bou Azzer inlier, Anti-Atlas Mountains. Precambrian Res. 2006, 147, 65-78. [CrossRef]

119. Inglis, J.; Hefferan, K.; Samson, S.; Admou, H.; Saquaque, A. Determining age of Pan African metamorphism using Sm-Nd garnet-whole rock geochronology and phase equilibria modeling in the Tasriwine ophiolite, Sirwa, Anti-Atlas, Morocco. J. Afr. Earth Sci. 2016, 127, 88-98. [CrossRef]

120. Youbi, N.; Ernst, R.; Söderlund, U.; Boumehdi, M.A.; Ait Lahna, A. Did the Central Iapetus Magmatic Province (CIMP) Event Both Trigger and End the c. 580 Ma Gaskiers Glaciation? In Proceedings of the Goldschmidt 2018 Abstracts, Boston, MA, USA, 12-17 August 2018; p. 2935. 